\title{
Shell chemistry of the boreal Campanian bivalve Rastellum diluvianum (Linnaeus, 1767) reveals temperature seasonality, growth rates and life cycle of an extinct Cretaceous oyster
}

\author{
Niels J. de Winter ${ }^{1, a}$, Clemens V. Ullmann ${ }^{2}$, Anne M. Sørensen ${ }^{3}$, Nicolas Thibault ${ }^{4}$, Steven Goderis ${ }^{1}$, \\ Stijn J. M. Van Malderen ${ }^{5}$, Christophe Snoeck ${ }^{1,6}$, Stijn Goolaerts ${ }^{7}$, Frank Vanhaecke ${ }^{5}$, and Philippe Claeys ${ }^{1}$ \\ ${ }^{1}$ AMGC research group, Vrije Universiteit Brussel, Pleinlaan 2, 1050 Brussels, Belgium \\ ${ }^{2}$ Camborne School of Mines, University of Exeter, Penryn, Cornwall, TR10 9FE, UK \\ ${ }^{3}$ Trap Danmark, Agem All 13, 2970, Hørsholm, Denmark \\ ${ }^{4}$ Department of Geoscience and Natural Resource Management, University of Copenhagen, \\ Øster Voldgade 10, 1350, Copenhagen, Denmark \\ ${ }^{5}$ A\&MS research unit, Ghent University, Campus Sterre, Krijgslaan 281, Building S12, 9000 Ghent, Belgium \\ ${ }^{6}$ G-Time Laboratory, Université Libre de Bruxelles, 50 Avenue F.D. Roosevelt, 1050 Brussels, Belgium \\ ${ }^{7}$ Directorate of Earth and History of Life, Royal Belgian Institute of Natural Sciences, \\ Vautierstraat 29, 1000 Brussels, Belgium \\ ${ }^{a}$ now at: Department of Earth Sciences, Faculty of Geosciences, Utrecht University, Utrecht, the Netherlands
}

Correspondence: Niels J. de Winter (niels.de.winter@vub.be)

Received: 1 March 2019 - Discussion started: 25 September 2019

Revised: 20 April 2020 - Accepted: 28 April 2020 - Published: 3 June 2020

\begin{abstract}
The Campanian age (Late Cretaceous) is characterized by a warm greenhouse climate with limited land-ice volume. This makes this period an ideal target for studying climate dynamics during greenhouse periods, which are essential for predictions of future climate change due to anthropogenic greenhouse gas emissions. Well-preserved fossil shells from the Campanian $( \pm 78 \mathrm{Ma})$ high mid-latitude $\left(50^{\circ} \mathrm{N}\right)$ coastal faunas of the Kristianstad Basin (southern Sweden) offer a unique snapshot of short-term climate and environmental variability, which complements existing longterm climate reconstructions. In this study, we apply a combination of high-resolution spatially resolved trace element analyses (micro-X-ray fluorescence $-\mu \mathrm{XRF}$ - and laser ablation inductively coupled plasma mass spectrometry - LAICP-MS), stable isotope analyses (IRMS) and growth modeling to study short-term (seasonal) variations recorded in the oyster species Rastellum diluvianum from the Ivö Klack locality. Geochemical records through 12 specimens shed light on the influence of specimen-specific and ontogenetic effects on the expression of seasonal variations in shell chemistry and allow disentangling vital effects from environmental in-
\end{abstract}

fluences in an effort to refine paleoseasonality reconstructions of Late Cretaceous greenhouse climates. Growth models based on stable oxygen isotope records yield information on the mode of life, circadian rhythm and reproductive cycle of these extinct oysters. This multi-proxy study reveals that mean annual temperatures in the Campanian higher midlatitudes were 17 to $19^{\circ} \mathrm{C}$, with winter minima of $\sim 13^{\circ} \mathrm{C}$ and summer maxima of $26^{\circ} \mathrm{C}$, assuming a Late Cretaceous seawater oxygen isotope composition of $-1 \%$ VSMOW (Vienna standard mean ocean water). These results yield smaller latitudinal differences in temperature seasonality in the Campanian compared to today. Latitudinal temperature gradients were similar to the present, contrasting with previous notions of "equable climate" during the Late Cretaceous. Our results also demonstrate that species-specific differences and uncertainties in the composition of Late Cretaceous seawater prevent trace element proxies $(\mathrm{Mg} / \mathrm{Ca}, \mathrm{Sr} / \mathrm{Ca}, \mathrm{Mg} / \mathrm{Li}$ and $\mathrm{Sr} / \mathrm{Li}$ ) from being used as reliable temperature proxies for fossil oyster shells. However, trace element profiles can serve as a quick tool for diagenesis screening and investigating seasonal growth patterns in ancient shells. 


\section{Introduction}

The Late Cretaceous was marked by a long cooling trend that brought global mean annual temperatures (MATs) down from the mid-Cretaceous climate maximum $\left( \pm 28^{\circ} \mathrm{C}\right.$ surface ocean temperatures) in the Cenomanian and Turonian ( $\pm 95 \mathrm{Ma}$ ) to slightly cooler temperatures $\left( \pm 22^{\circ} \mathrm{C}\right.$ surface ocean temperatures) around the Campanian-Maastrichtian boundary $( \pm 72.1 \mathrm{Ma}$; Clarke and Jenkyns, 1999; Pearson et al., 2001; Huber et al., 2002; Friedrich et al., 2012; Scotese, 2016). This cooling trend was likely caused by a change in ocean circulation, initiated by the opening of the Equatorial Atlantic Gateway that separated the proto-North and protoSouth Atlantic Ocean basins (Friedrich et al., 2009). The cooling trend is well documented in stable oxygen isotope records from the white-chalk successions of the Chalk Sea, which covered large portions of northwestern Europe during the Late Cretaceous period (Reid, 1973; Jenkyns et al., 1994; Jarvis et al., 2002; Voigt et al., 2010). The connection of the Chalk Sea to the (proto-)North Atlantic Ocean makes it an interesting area of study to constrain Late Cretaceous paleogeography and climate. These chalk successions are featured in various paleoclimate studies because they are accessible in good outcrops and consist predominantly of calcareous nannofossils which were thought to faithfully record sea surface conditions (e.g., Jenkyns et al., 1994). However, recent studies (e.g., O'Brien et al., 2017; Tagliavento et al., 2019) have shown that diagenetic overprinting likely biases these records towards cooler temperatures, resulting in the apparent cool tropics paradox (Pearson et al., 2001). Even though sea level changes seem to indicate possible small changes in land-ice volume during the Late Cretaceous, warm high-latitude paleotemperatures likely rule out the possibility of extensive polar ice sheets comparable in volume to modern ice caps (Barrera and Johnson, 1999; Huber et al., 2002; Jenkyns et al., 2004; Miller et al., 2005; Thibault et al., 2016).

Given its warm, essentially land-ice-free conditions, the Campanian serves as an interesting analogue for Earth's climate in the future, should anthropogenic and natural emissions continue to contribute to the rise in global temperatures and decrease in global ice volume on Earth (IPCC, 2013; Donnadieu et al., 2016). However, most Late Cretaceous climate reconstructions focus on reconstructing and modeling long-term evolutions of humid or arid conditions on land or past atmospheric and oceanic temperatures (DeConto et al., 1999; Thibault et al., 2016; Yang et al., 2018). Data on the extent of seasonal variability from this time period, especially outside the tropics, are scarce, although seasonality constitutes a fundamental component of the climate system (Steuber, 1999; Steuber et al., 2005; Burgener et al., 2018). Furthermore, many proxies used for paleoclimate reconstruction risk seasonal bias, and thus independent seasonality reconstructions serve as important tools to verify other climate reconstructions.

\section{Background}

\subsection{Geological setting}

The Kristianstad Basin, our study site, is located on the southeastern Baltic Sea coast of the southern Swedish province of Scania, which is presently located at $56^{\circ} 2^{\prime} \mathrm{N}$, $14^{\circ} 9^{\prime} \mathrm{E}$ (see Fig. 1), somewhat higher than its Campanian paleolatitude, which is estimated at $50^{\circ} \mathrm{N}$ (van Hinsbergen et al., 2015). The uppermost lower Campanian shallow-marine sediments deposited at Ivö Klack consist of sandy and silty nearshore deposits containing carbonate gravel (Christensen, 1975, 1984; Surlyk and Sørensen, 2010; Sørensen et al., 2015). The depositional setting is described as a rocky coastline that was inundated during the maximum extent of the Late Cretaceous transgression (Kominz et al., 2008; CsikiSava et al., 2015). Since the region has remained tectonically quiet since the Campanian, the deposits of Kristianstad Basin localities remain at roughly the same altitude as when they were deposited and have been subject to limited burial (Christensen, 1984; Surlyk and Sørensen, 2010).

The rocky-shore deposits of Ivö Klack are characterized by a diverse shelly fauna, consisting of well-preserved fossils and fragments of brachiopods, belemnites, echinoids and asteroids, polychaete worms, gastropods, corals, ammonites, and thick-shelled oysters, with a total of almost 200 different recognized species (Surlyk and Sørensen, 2010). In this diverse rocky-shore ecosystem, various habitat zones can be distinguished, each with their distinct suite of organisms adapted to local conditions of varying amounts of sunlight, sedimentation and turbulence (Surlyk and Christensen, 1974; Sørensen et al., 2012). This unique combination of marine biodiversity and preservation of original calcite shell material makes the localities in the Kristianstad Basin ideal for studying sub-annual variability in shell chemistry and reconstructing paleoseasonality and environmental change in the Campanian (Sørensen et al., 2015).

\subsection{Bivalve shells}

Fossil bivalve shells offer a valuable archive for studying past climates on a seasonal scale. Incremental measurements of shell chemistry in the growth direction (sclerochronology studies) potentially yield records of seasonal changes in the environment (Mook, 1971; Jones, 1983; Klein et al., 1996a; Schöne and Gillikin, 2013). Their distribution allows paleoseasonality reconstructions from bivalves across a wide range of latitudes (Roy et al., 2000; Jablonski et al., 2017), and the preservation potential of calcitic shell structures (especially in oyster shells) makes them ideal, if not unique, recorders of pre-Quaternary seasonality and sub-annual environmental change (Brand and Veizer, 1980; 1981; Al-Aasm and Veizer, 1986a, b; Immenhauser et al., 2005; Alberti et al., 2017). The incremental deposition of shell carbonate means, in theory, that the limits in terms of time resolution of the 
bivalve shell archive are governed by sampling resolution rather than the resolution of the record itself. While periods of growth cessation can occur (especially in high latitudes; Ullmann et al., 2010) and the true mechanisms of shell deposition at a very high (e.g., daily) temporal resolution are poorly constrained (see de Winter et al., 2020a, and references therein), in practice incremental shell deposition allows reconstructions of changes down to sub-daily timescales given the right sampling techniques (Schöne et al., 2005; Sano et al., 2012; Warter et al., 2018; de Winter et al., 2020a). Examples of chemical proxies used in such sclerochronology studies include stable carbon and oxygen isotope ratios and trace element ratios (e.g., Steuber et al., 2005; Gillikin et al., 2006; McConnaughey and Gillikin, 2008; Schöne et al., 2011; de Winter et al., 2017a, 2018).

\subsection{Trace element proxies}

The incorporation of trace elements and carbon isotopes into bivalve shells is influenced by so-called vital effects: biological controls on the incorporation of elements in the shell independent of the environment (Weiner and Dove, 2003; Gillikin et al., 2005). These vital effects have been shown to mask the characteristic relationships between shell trace element chemistry and the environment and appear to be distinct not only between different bivalve species but also between specimens of different ontogenetic age (Freitas et al., 2008). Differences between bivalve families mean that the trace element chemistry of some taxa (like scallops: family Pectinidae) are especially affected by vital effects (Lorrain et al., 2005; Freitas et al., 2008), while other families like oysters (family Ostreidae) seem to be more robust recorders of environmental conditions (Surge et al., 2001; Surge and Lohmann, 2008; Ullmann et al., 2010, 2013). The effect on shell composition and preservation of changes in microstructure and the amount of organic matrix present in different shell layers introduce uncertainty as to which parts of the shells are well-suited for reconstruction purposes (Carriker et al., 1991; Kawaguchi et al., 1993; Dalbeck et al., 2006; Schöne et al., 2010, 2013). The key to disentangling vital effects from recorded environmental changes lies in the application of multiple proxies and techniques on the same bivalve shells (the "multi-proxy approach"; e.g., Ullmann et al., 2013; de Winter et al., 2017a, 2018) and basing reconstructions on more than one shell (Ivany, 2012).

\subsection{Stable isotope ratios}

Because nearly all bivalves precipitate their shells at or near oxygen isotope equilibrium, the stable oxygen isotope ratio of bivalve shell carbonate is less susceptible to vital effects, such as growth kinetics (Uchikawa and Zeebe, 2012). Therefore, stable oxygen isotope ratios in bivalve shell carbonate $\left(\delta^{18} \mathrm{O}_{\mathrm{c}}\right)$ are solely dependent on calcification temperature and seawater oxygen isotope composition $\left(\delta^{18} \mathrm{O}_{\mathrm{sw}}\right)$, and this proxy is frequently used in sclerochronology studies as a paleothermometer (Kim and O'Neil, 1997; Schöne et al., 2005; Butler et al., 2013; Ullmann et al., 2013; Huyghe et al., 2015; de Winter et al., 2020b). Oxygen isotope records can function as a reference in the above-mentioned multiproxy studies aimed at resolving vital effects and environmental and climatic changes. However, the weakness of this proxy lies in the fact that $\delta^{18} \mathrm{O}_{\mathrm{sw}}$ is not always known, especially in deep-time settings (Veizer and Prokoph, 2015). As a result, a constant $\delta^{18} \mathrm{O}_{\text {sw }}$ of $0 \%$ VSMOW (Vienna standard mean ocean water) for modern icehouse climate conditions, or $-1 \%$ VSMOW for an ice-free world (such as the Eocene or the Late Cretaceous; after Shackleton, 1986), is often assumed (e.g., Andreasson and Schmitz, 1996; Ivany and Runnegar, 2010; Huyghe et al., 2015). An offset of $1 \%$ o between assumed $\delta^{18} \mathrm{O}_{\text {sw }}$ and actual $\delta^{18} \mathrm{O}_{\mathrm{sw}}$ can result in a $\sim 4.6{ }^{\circ} \mathrm{C}$ temperature offset in temperature reconstructions (Kim and O'Neil, 1997). This assumption may therefore introduce inaccuracies in absolute temperature reconstructions, but relative variations in $\delta^{18} \mathrm{O}_{\mathrm{c}}$ can still yield important insights into high-resolution climate dynamics.

In marine mollusks, dissolved inorganic carbon (DIC) in the ambient seawater contributes the largest fraction of carbon $(90 \%)$ used for shell mineralization (McConnaughey, 2003; Gillikin et al., 2007) and therefore heavily influences $\delta^{13} \mathrm{C}$ values of shell carbonate. However, changes in respiration rates can alter the carbon budget of shell carbonate by adding or removing isotopically light respired carbon in the form of $\mathrm{CO}_{2}$ (Lorrain et al., 2004). Environmental changes in DIC can also have a strong influence on this carbon budget, especially when bivalves grow in nearshore or estuarine conditions with large (seasonal) variations in environmental $\delta^{13} \mathrm{C}$ of DIC and organic carbon (Gillikin et al., 2006). Conceptual models exist that attempt to correlate shell $\delta^{13} \mathrm{C}$ in modern mollusks to environmental and physiological variations, but these require knowledge of ambient $\mathrm{CO}_{2}$ pressures and $\delta^{13} \mathrm{C}$ values of DIC, gas ventilation rates in the animal, and $\mathrm{CO}_{2}$ and $\mathrm{O}_{2}$ permeabilities of calcifying membranes (McConnaughey et al., 1997), which are not available in fossil bivalve studies.

\subsection{Aim}

In this study, we present a detailed, multi-proxy comparison of the growth and chemistry of well-preserved fossil shells of the thick-shelled oyster Rastellum diluvianum (Linnaeus, 1767) recovered from the Ivö Klack locality on the northern edge of the Kristianstad Basin. We combine stable isotope proxies, conventional in sclerochronological studies $\left(\delta^{13} \mathrm{C}\right.$ and $\delta^{18} \mathrm{O}$; e.g., Goodwin et al., 2001; Steuber et al., 2005), with less well established trace element proxies $(\mathrm{Mg} / \mathrm{Ca}$, $\mathrm{Sr} / \mathrm{Ca}, \mathrm{Mg} / \mathrm{Li}$ and $\mathrm{Sr} / \mathrm{Li}$; e.g., Bryan and Marchitto, 2008; Schöne et al., 2011; Füllenbach et al., 2015; Dellinger et al., 2018) and growth modeling based on $\delta^{18} \mathrm{O}$ seasonality (Judd et al., 2018) in an attempt to disentangle the effects of 

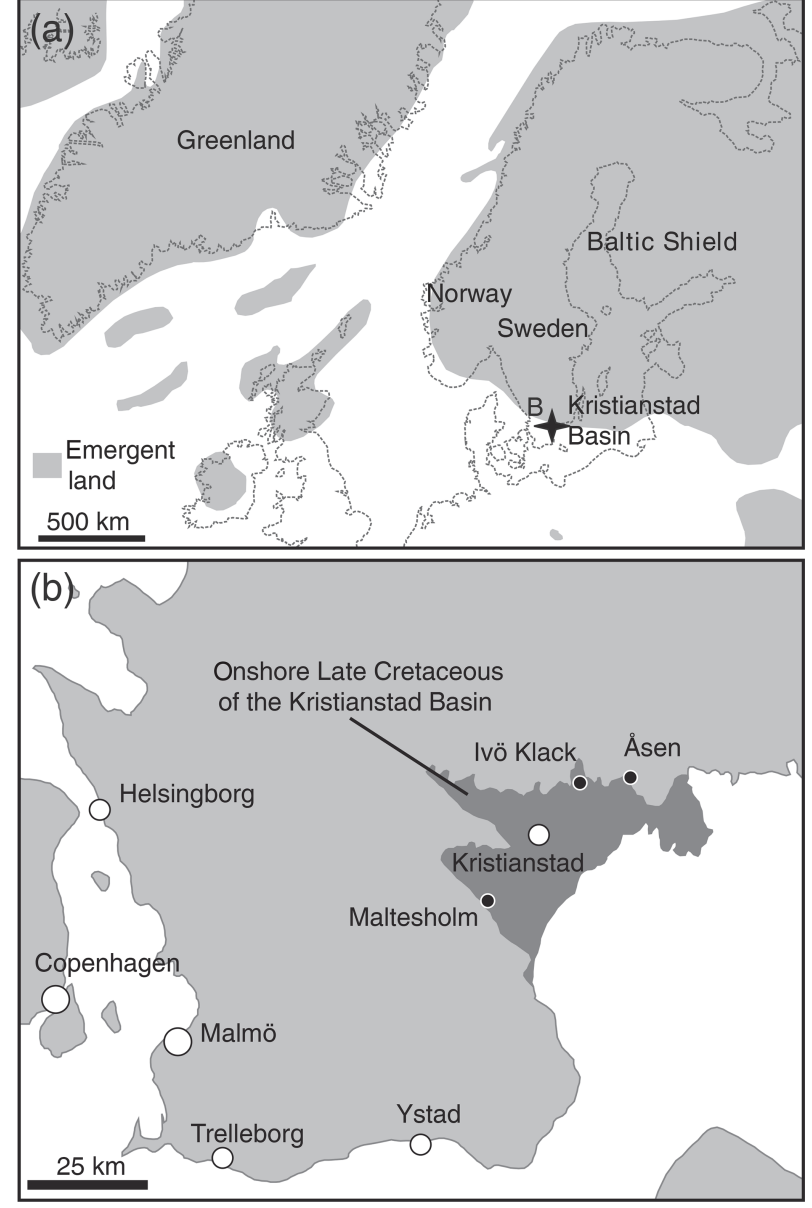

Figure 1. Paleogeographic map of the Boreal Chalk Sea (a) and the area of present-day southern Sweden (b) showing the location of Ivö Klack (modified after Sørensen et al., 2015).

growth rate, reproductive cycle and environmental change on shell chemistry. The data gathered in this study allow a detailed discussion on seasonal changes in temperature and water chemistry in the coastal waters of the Kristianstad Basin in the late early Campanian as well as on the life cycle of $R$. diluvianum and its response to seasonal changes in its environment.

\section{Materials and methods}

\subsection{Sample acquisition and preparation}

Complete valves of 12 individual $R$. diluvianum oysters were obtained from the Ivö Klack locality (see Fig. 2). Specimens of $R$. diluvianum were found in situ attached to the vertical sides of large boulders that characterized the rocky shore of Ivö Klack (Surlyk and Christensen, 1974) and are biostratigraphically assigned to the latest early Campanian Belemnellocamax mammilatus belemnite zone. The valves were cleaned and fully embedded in Araldite ${ }^{\circledR} 2020$ epoxy resin (Bodo Möller Chemie Benelux, Antwerp, Belgium). Dorsoventral slabs $( \pm 10 \mathrm{~mm}$ thick) were cut perpendicular to the hinge line using a water-cooled slow-rotating saw with a diamond-coated blade (thickness $\pm 1 \mathrm{~mm}$; Fig. 2). The surfaces cut on the central growth axis were progressively polished using silicon-carbide polishing disks (up to P2500, or $8.4 \mu \mathrm{m}$ grain size). Polished surfaces were scanned at high (6400 dpi) resolution using an Epson Perfection 1650 flatbed color scanner (Seiko Epson Corp., Suwa, Japan). Resulting color scans of all polished $R$. diluvianum shell cross sections are provided in Fig. 2 and Fig. S1 from de Winter et al. (2020c, https://doi.org/10.5281/zenodo.2581304). Shell microstructures in $R$. diluvianum shells were studied in detail on high-resolution scans and by using reflected-light optical microscopy. Microstructural features were used to reconstruct the relative timing of shell growth (see Fig. 3). Fragments of visually well-preserved material from different microstructures in the shells were coated with gold and studied under a scanning electron microscope (SEM; Quanta 200 ESEM) and imaged at $1000 \times-2000 \times$ magnification (Fig. 3b-e). Chemical analyses were carried out sequentially on polished cross sections in order of destructive character of sampling (starting with the least-destructive measurements: micro-X-ray fluorescence $-\mu \mathrm{XRF}$, laser ablation inductively coupled plasma mass spectrometry - LA-ICP-MS, microdrilling for IRMS and finally multi-cup inductively coupled plasma mass spectrometry - MC-ICP-MS - analysis on $\sim 26 \mathrm{mg}$ samples).

\subsection{Micro-XRF mapping}

Elemental abundance maps of all $R$. diluvianum shell cross sections were obtained using a Bruker Tornado M4 energydispersive micro-X-ray fluorescence scanner ( $\mu \mathrm{XRF}$; Bruker Nano GmbH, Berlin, Germany). All $\mu \mathrm{XRF}$ analyses carried out with the Bruker M4 Tornado are non-destructive. $\mu \mathrm{XRF}$ is equipped with a $\mathrm{Rh}$ filament metal-ceramic-tube X-ray source operated at $50 \mathrm{kV}$ and $600 \mu \mathrm{A}(30 \mathrm{~W}$; maximum energy settings). The circular spot projected on the same surface is estimated to have a diameter of $25 \mu \mathrm{m}$ (Mo $\mathrm{K} \alpha$ ). A micrometer-precision XYZ translation stage allows for quick and precise sample movement such that a grid of $25 \mu \mathrm{m} \mathrm{XRF}$ spots can be measured on the sample surface by continuous scanning to construct elemental maps $\left(3 \times 10^{6}-5 \times 10^{6}\right.$ pixels per map). Exposure times of the X-ray beam per sampling position in mapping mode ( $1 \mathrm{~ms}$ per pixel) are too short to gain an adequate signal-to-noise ratio for pixel-by-pixel quantification of elemental concentrations. Instead, processing of entire map surfaces using the Bruker ESPRIT ${ }^{\mathrm{TM}}$ software allows semi-quantitative elemental abundance maps to be created of the sample surface based on a mapping of the count rate in "Regions of Interest" of elements (see de Winter and Claeys, 2016; de Winter et al., 2017b; Fig. 3). XRF maps allow for a rapid assessment of the preservation state of original shell calcite based on variations in $\mathrm{Si}, \mathrm{Mn}, \mathrm{Fe}$ and $\mathrm{Sr}$ 


\section{Overview of Rastellum diluvianum shells}

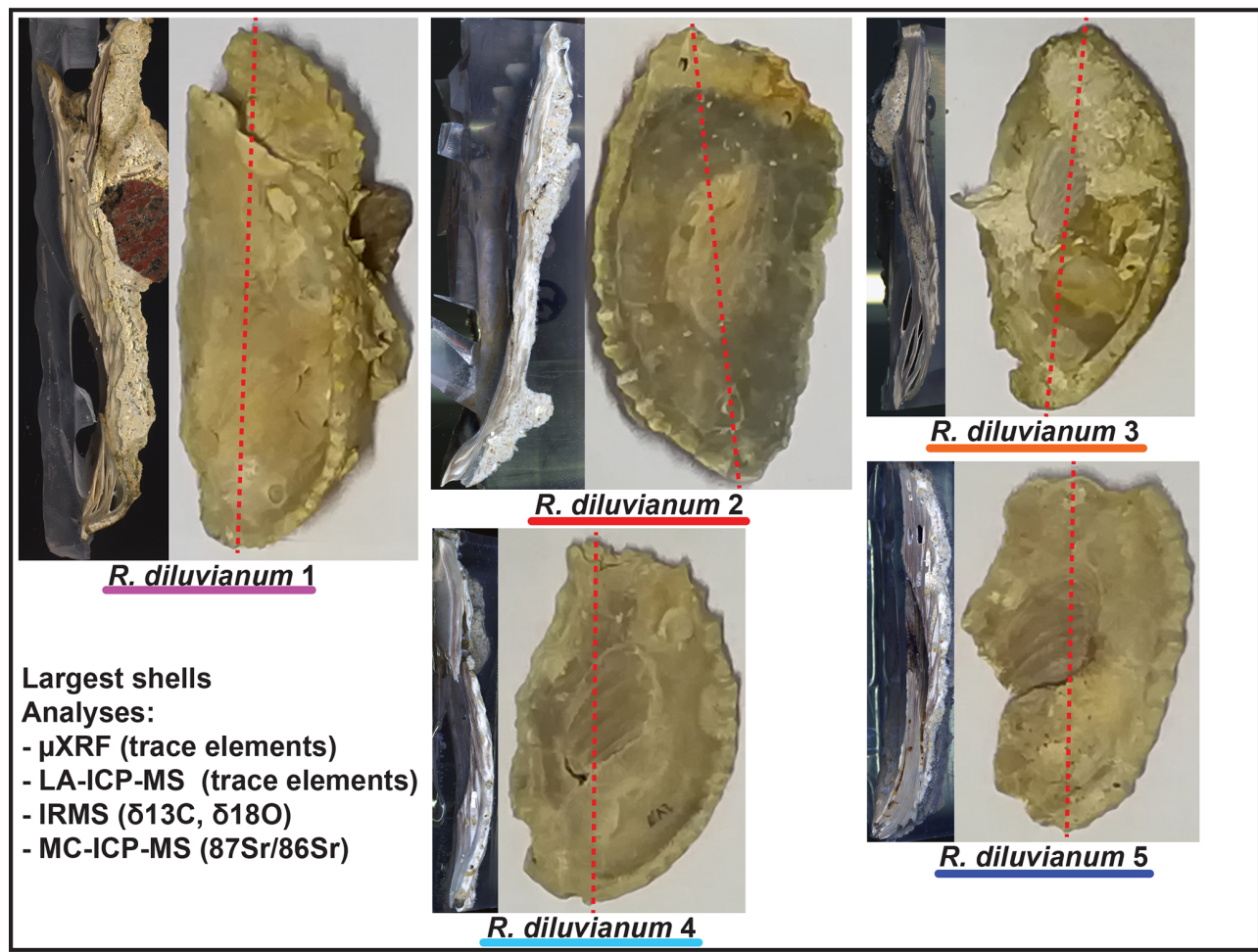

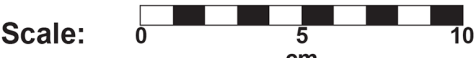

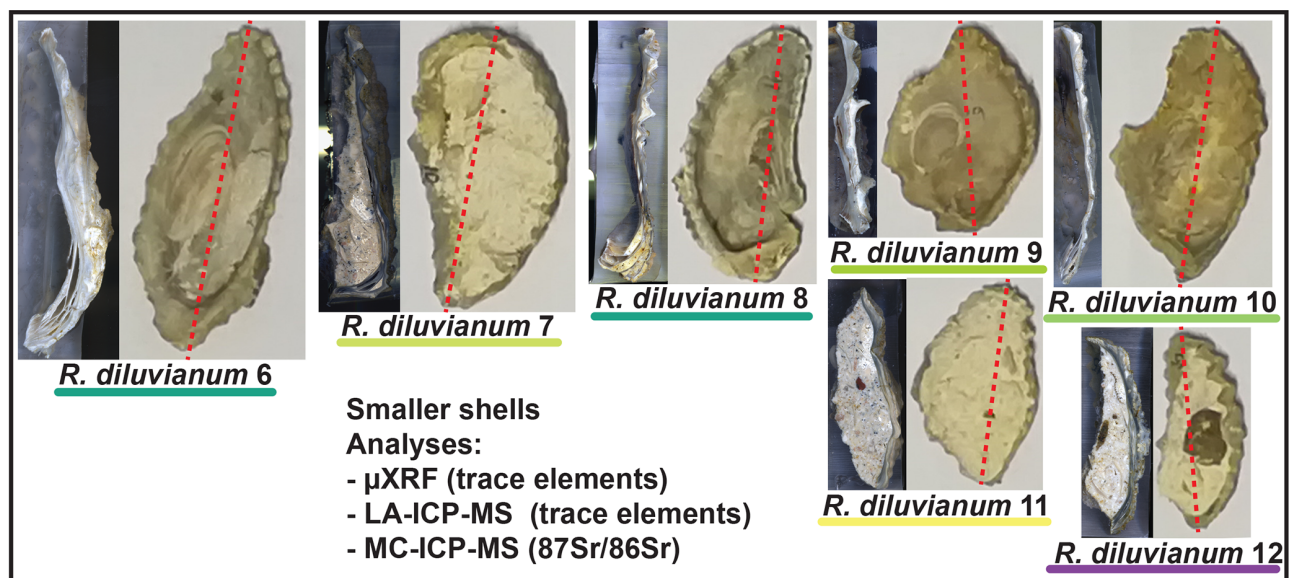

Figure 2. Overview of the 12 Rastellum diluvianum shells used in this study. All shells are depicted at the same scale (see scale bar in center of image). Colors of the lines under sample names correspond to the colors of the lines in Figs. 4, 6, 8 and 10. Every shell is represented by an image of the inside of the valve analyzed as well as a color scan of the cross section through the shell on which high-resolution analyses were carried out. Dashed red lines show the location of these cross sections. The largest five shells (1-5, in top panel) were sampled for IRMS analyses $\left(\delta^{13} \mathrm{C}\right.$ and $\left.\delta^{18} \mathrm{O}\right)$. All shells were subjected to micro-X-ray fluorescence $(\mu \mathrm{XRF})$, laser ablation inductively coupled plasma mass spectrometry (LA-ICP-MS) and multi-cup inductively coupled plasma mass spectrometry (MC-ICP-MS) analyses. Full-size versions of the high-resolution color scans of shell cross sections are provided in de Winter et al. (2020c). 

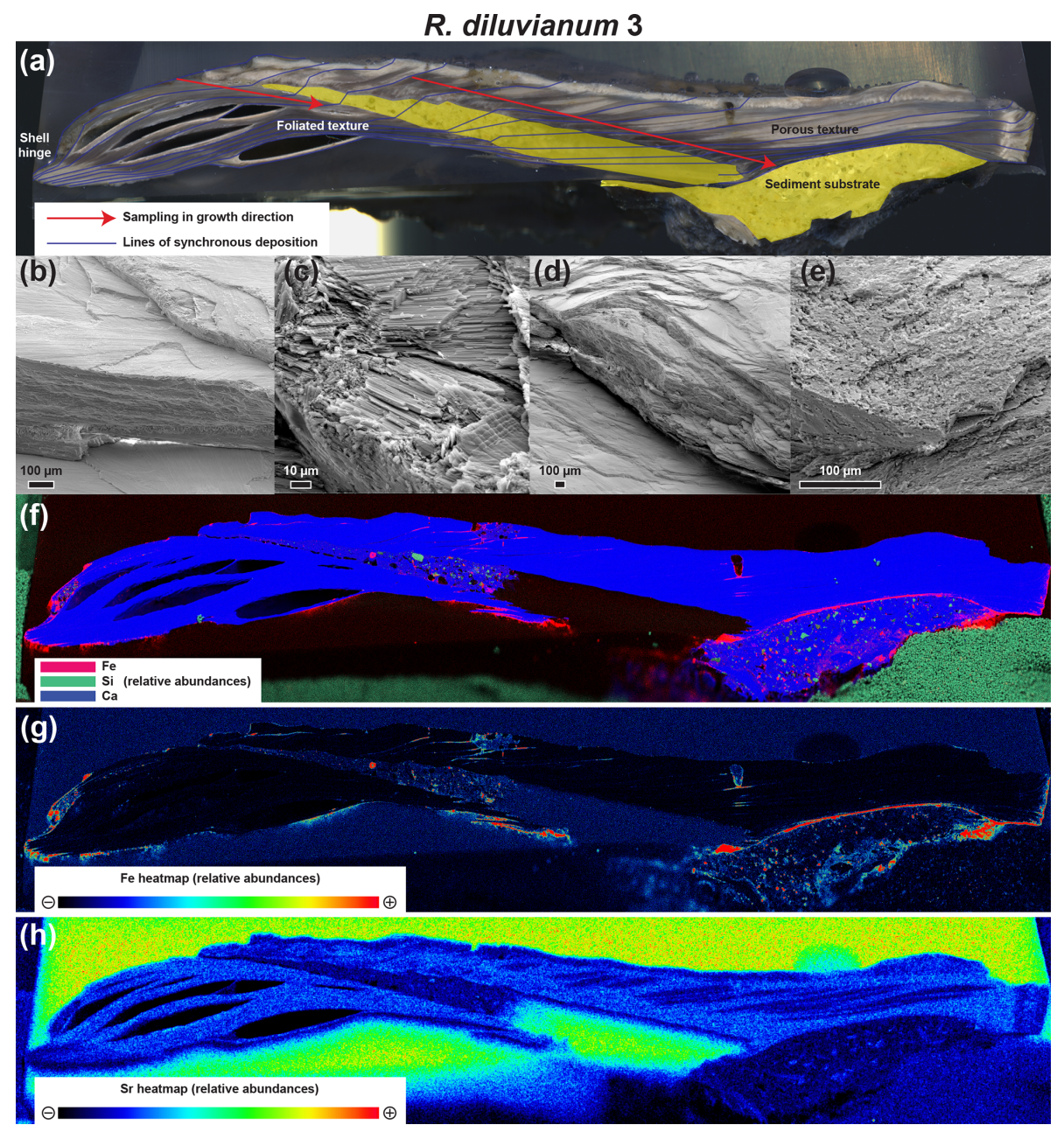

Figure 3. Overview image showing a high-resolution color scan of the cross section through $R$. diluvianum (a) on which the different shell textures as well as the directions of high-resolution analyses (in growth direction) are indicated. Thin blue lines denote parts of the shell that were deposited at the same time (growth increments). Areas marked in yellow represent sediment infilling below and within the valves. (b) and (c) show SEM images of the well-preserved foliated calcite in the shell. More porous structures in the shell (vesicular calcite) are depicted in SEM images shown in (d) and (e). Below are three XRF elemental maps of the same cross section: an RGB-colored map displaying the relative abundances of $\mathrm{Fe}, \mathrm{Si}$ and $\mathrm{Ca}(\mathbf{f})$; a heatmap of Fe concentrations (g; see scale bar below map) and a heatmap of Sr concentrations (h; see scale bar below map). XRF mapping only yields relative (semi-quantitative) abundance of elements.

concentrations and guide the formulation of sampling protocols for further analyses (de Winter and Claeys, 2016; Fig. 3). Results of XRF mapping on all $12 R$. diluvianum shell cross sections are provided in Fig. S2 from de Winter et al. (2020c).

\subsection{Micro-XRF line scans}

After XRF mapping, quantitative line scans were measured in the growth direction on shell cross sections. Dwell times of $60 \mathrm{~s}$ per measurement allowed sufficiently high signal-tonoise ratios for individual points in line scans to be quantified. This acquisition time was chosen so as to provide the optimal compromise between increasing run time (improved signal-to-noise ratio; enhanced reproducibility) and increasing the number of sampling positions (improving sampling density and allowing duplicate measurements) for the elements $\mathrm{Mg}, \mathrm{Al}, \mathrm{Si}, \mathrm{P}, \mathrm{S}, \mathrm{Ca}, \mathrm{Ti}, \mathrm{Mn}, \mathrm{Fe}, \mathrm{Cu}, \mathrm{Zn}$ and $\mathrm{Sr}$ (see discussion in de Winter et al., 2017b). The sampling interval of line scans was $50 \mu \mathrm{m}$, adding up to a total of 11056 individual quantitative XRF spectra measured for this study. Spectra were quantified using the Bruker ESPRIT software calibrated using the matrix-matched BAS-CRM393 limestone standard (Bureau of Analysed Samples, Middlesbrough, UK), after which individual measurements were calibrated offline using seven matrix-matched certified reference materials (CCH1, COQ1, CRM393, CRM512, CRM513, ECRM782 and SRM1d), which were treated as samples (see Vansteenberge et al., 2020). $R^{2}$ values of calibration curves exceeded 0.99 , and reproducibility standard deviations were better than $10 \%$ relative to the mean. Even though line 
scans were positioned on well-preserved shell calcite based on the XRF map results, a second check was carried out in which individual points were rejected based on conservative thresholds for diagenetic recrystallization or detrital contamination $\left([\mathrm{Ca}]<38 \mathrm{wt} \%\right.$, [Si] $>1 \mathrm{wt} \%,[\mathrm{Mn}]>200 \mu \mathrm{g} \mathrm{g}^{-1}$ or $[\mathrm{Fe}]>250 \mu \mathrm{g} \mathrm{g}^{-1} ;[\mathrm{Sr}] /[\mathrm{Mn}]<100 \mathrm{~mol} \mathrm{~mol}^{-1}$; see Al-Aasm and Veizer, 1986a; Sørensen et al., 2015). Concentrations of $\mathrm{Ca}, \mathrm{Mg}$ and $\mathrm{Sr}$ in well-preserved shell sections were used to explore the potential of $\mathrm{Mg} / \mathrm{Ca}$ and $\mathrm{Sr} / \mathrm{Ca}$ molar ratios as paleoenvironmental proxies. Unprocessed results of XRF line scanning are provided in Fig. S3 from de Winter et al. (2020c).

\subsection{LA-ICP-MS line scans}

Spatially resolved elemental concentrations for $\mathrm{Li}, \mathrm{B}, \mathrm{Mg}, \mathrm{Si}$, $\mathrm{P}, \mathrm{Ca}, \mathrm{Ti}, \mathrm{V}, \mathrm{Cr}, \mathrm{Mn}, \mathrm{Fe}, \mathrm{Ni}, \mathrm{Zn}, \mathrm{Rb}, \mathrm{Sr}, \mathrm{Ba}, \mathrm{Pb}$ and $\mathrm{U}$ were calculated from a calibrated transient MS signal recorded during LA-ICP-MS line scanning in the growth direction (parallel to the XRF line scans) on shell cross sections. LAICP-MS measurements were carried out at the Atomic \& Mass Spectrometry - A\&MS - research unit of Ghent University (Ghent, Belgium) using a $193 \mathrm{~nm} \mathrm{ArF*excimer-based}$ Analyte G2 laser ablation system (Teledyne Photon Machines, Bozeman, USA), equipped with a HelEx 2 doublevolume ablation cell, coupled to an Agilent 7900 quadrupolebased ICP-MS unit (Agilent, Tokyo, Japan). Continuous scanning along shell transects using a laser spot with a diameter of $25 \mu \mathrm{m}$, scan speed of $50 \mu \mathrm{m} \mathrm{s}^{-1}$ and detector mass sweep time of $0.5 \mathrm{~s}$ yielded profiles with a lateral sampling interval of $25 \mu \mathrm{m}$, amounting to a total of 9505 LA-ICP-MS data points gathered. The aerosol was transported using He carrier gas into the ICP-MS unit via the aerosol rapid introduction system (ARIS; Teledyne Photon Machines, Bozeman, USA). Elemental concentrations were calibrated using bracketed analysis runs on US Geological Survey (USGS) BCR-2G, BHVO-2G, BIR-1G, GSD-1G and GSE-1G and National Institute of Standards and Technology (NIST) SRM612 and SRM610 certified reference materials. Calcium concentrations (measured via ${ }^{43} \mathrm{Ca}$ ) were used as an internal standard for data normalization and drift correction during the measurement campaign, and $\mathrm{Ca}$ concentrations of $38.5 \mathrm{wt} \%$ were assumed for pristine shell carbonate. Coefficients of determination $\left(R^{2}\right)$ of a linear model fitted to the calibration curves were better than 0.99 , and the standard deviation of reproducibility for elemental concentrations was better than $5 \%$ relative to the mean value. Individual LAICP-MS measurements were inspected for diagenetic alteration or contamination by detrital material using the same thresholds as those used for XRF data (see above). LAICP-MS and $\mu$ XRF measurements were combined to cover a wider range of elements, since some elements (e.g., $\mathrm{S}$ and $\mathrm{Sr}$ ) were measured more reliably using $\mu \mathrm{XRF}$, while others (e.g., $\mathrm{Li}$ or $\mathrm{Ba}$ ) could only be quantified using LA-ICP-MS. Concentrations of $\mathrm{Li}, \mathrm{Mg}$ and $\mathrm{Sr}$ were used to explore the poten- tial of $\mathrm{Mg} / \mathrm{Li}$ and $\mathrm{Sr} / \mathrm{Li}$ molar ratios as proxies for paleoenvironmental change. Unprocessed results of LA-ICP-MS line scans are provided in Fig. S4 from de Winter et al. (2020c).

\subsection{Isotope ratio mass spectrometry}

A transect of powdered samples $( \pm 200 \mu \mathrm{g})$ was extracted for isotope ratio mass spectrometry (IRMS) analysis in the growth direction along well-preserved foliated calcite (Fig. 3) in the 5 largest of the $12 R$. diluvianum shells ( $R$. diluvianum 1-5; see Fig. 2) using a microdrill (Merchantek/Electro Scientific Industries Inc., Portland, OR, USA) equipped with a $300 \mu \mathrm{m}$ diameter tungsten carbide drill bit, coupled to a microscope (Leica GZ6, Leica Microsystems GmbH, Wetzlar, Germany). A total of 531 IRMS samples were taken at an interspacing of $250 \mu \mathrm{m}$. Stable carbon and oxygen isotope ratios $\left(\delta^{13} \mathrm{C}\right.$ and $\left.\delta^{18} \mathrm{O}\right)$ were measured in a Nu Perspective IRMS equipped with a NuCarb carbonate preparation device ( $\mathrm{Nu}$ Instruments, UK). The sample size $(50-100 \mu \mathrm{g})$ allowed duplicate measurements to be carried out regularly (roughly once every 30 samples) to assess reproducibility. Samples were digested in $104 \%$ phosphoric acid at a constant temperature of $70^{\circ} \mathrm{C}$, and the resulting $\mathrm{CO}_{2}$ gas was cryogenically purified before being led into the IRMS through a dual-inlet system. Isotope ratios were corrected for instrumental drift and fractionation due to variations in sample size, and the resulting values are reported relative to the Vienna Pee Dee Belemnite standard (\%o VPDB) using repeated measurements of the IA-603 stable isotope standard (International Atomic Energy Agency, Vienna, Austria). Reproducibility of $\delta^{18} \mathrm{O}$ and $\delta^{13} \mathrm{C}$ measurements on this standard were better than $0.1 \%$ and $0.05 \% \circ(1 \sigma ; N=125)$, respectively. All stable isotope analysis results are provided in Fig. S5 from de Winter et al. (2020c), and plots of stable isotope and trace element records from all shells are given in Fig. S6 from de Winter et al. (2020c).

\subsection{Growth and age modeling}

Stable oxygen isotope curves measured in $R$. diluvianum were used to produce age models for the growth of the shell using a bivalve growth model written in MATLAB (MathWorks, Natick, MA, USA) which simulates $\delta^{18} \mathrm{O}$ curves using a combination of growth and temperature sinusoids (Judd et al., 2018). This simulation model was modified to calculate its temperatures based on calcite $\delta^{18} \mathrm{O}$ (following Kim and O'Neil, 1997) rather than from the aragonite $\delta^{18} \mathrm{O}-$ temperature relationship used in the original approach (after Grossman and $\mathrm{Ku}, 1986$; see Judd et al., 2018). A value of $-1.0 \%$ VSMOW was assumed for $\delta^{18} \mathrm{O}$ of Campanian ocean water (Shackleton, 1986; Thibault et al., 2016). Additional minor modifications in the source code allowed results of intermediate calculation steps in the model to be exported. The modified MATLAB source code is provided in Fig. S7 from de Winter et al. (2020c). Note that this model 
assumes that the shape and absolute value of $\delta^{18} \mathrm{O}$ curves depend solely on water temperature and growth rate (ignoring changes in $\delta^{18} \mathrm{O}_{\mathrm{sw}}$ ) and that a modeled year contains $365 \mathrm{~d}$ by construction (while this number should be slightly larger in the Late Cretaceous; de Winter et al., 2020a). Despite these caveats, shell chronologies reconstructed from seasonal patterns in $\delta^{18} \mathrm{O}$ should still be reliable, as they are only based on the shape of the $\delta^{18} \mathrm{O}$ curves. Uncertainties of modeled temperature curves were derived by propagating the measurement uncertainty of $\delta^{18} \mathrm{O}$. Age models thus obtained for shells $R$. diluvianum $1-5$ were used to align all proxy records on a common time axis. Age models for R.diluvianum 612 were constructed by extrapolating relationships between modeled seasonality and microstructures and trace element concentrations observed in $R$. diluvianum 1-5. Simultaneously deposited microstructural features in shell cross sections (see Fig. 3) were used to determine the actual dorsoventral height of the shells at different ages, linking shell height to the age and allowing the construction of growth curves for all $12 R$. diluvianum shells. The total age and the season of spawning (or the start of shell growth) were determined by extrapolating the $\delta^{18} \mathrm{O}$-based age models and by using the relationship between $\delta^{18} \mathrm{O}$ profiles and trace element records and growth increments observed in the shell.

\subsection{Strontium isotope analysis}

Samples (on average $26 \mathrm{mg}$ ) for strontium isotope analysis were obtained by drilling the well-preserved foliated calcite in all shells using a Dremel 3000 dental drill with a $0.5 \mathrm{~mm}$ tungsten carbide drill bit. Calcite samples were placed in Teflon beakers (Savillex LLC, Eden Prairie, MN, USA), dissolved in subboiled concentrated $(14 \mathrm{M})$ nitric acid $\left(\mathrm{HNO}_{3}\right)$ at $120^{\circ} \mathrm{C}$ and left to dry at $90^{\circ} \mathrm{C}$ overnight, after which the residue was redissolved in $2 \mathrm{M} \mathrm{HNO}_{3}$. Carbonate-bound strontium in the samples was purified following the ionexchange resin chromatography method detailed in Snoeck et al. (2015). The ${ }^{87} \mathrm{Sr} /{ }^{86} \mathrm{Sr}$ of purified $\mathrm{Sr}$ samples was determined using a $\mathrm{Nu}$ Plasma (Nu Instruments Ltd, Wrexham, UK) multi-collector (MC) ICP-MS unit in operation at the Université Libre de Bruxelles (ULB). During the measurement run, repeated analyses of NIST SRM987 standard solution yielded a ratio of $0.710250 \pm 0.000040(2 \mathrm{SD} ; N=14)$, statistically consistent with the literature value of $0.710248 \pm$ 0.000058 (2 SE; McArthur et al., 2001; Weis et al., 2006). All results were corrected for instrumental mass discrimination by internal normalization and normalized to the literature value of NIST SRM987 (0.710248) through a standardsample bracketing method. For each sample, ${ }^{87} \mathrm{Sr} /{ }^{86} \mathrm{Sr}$ values are reported with $2 \sigma$ uncertainty (Fig. S8 from de Winter et al., 2020c).

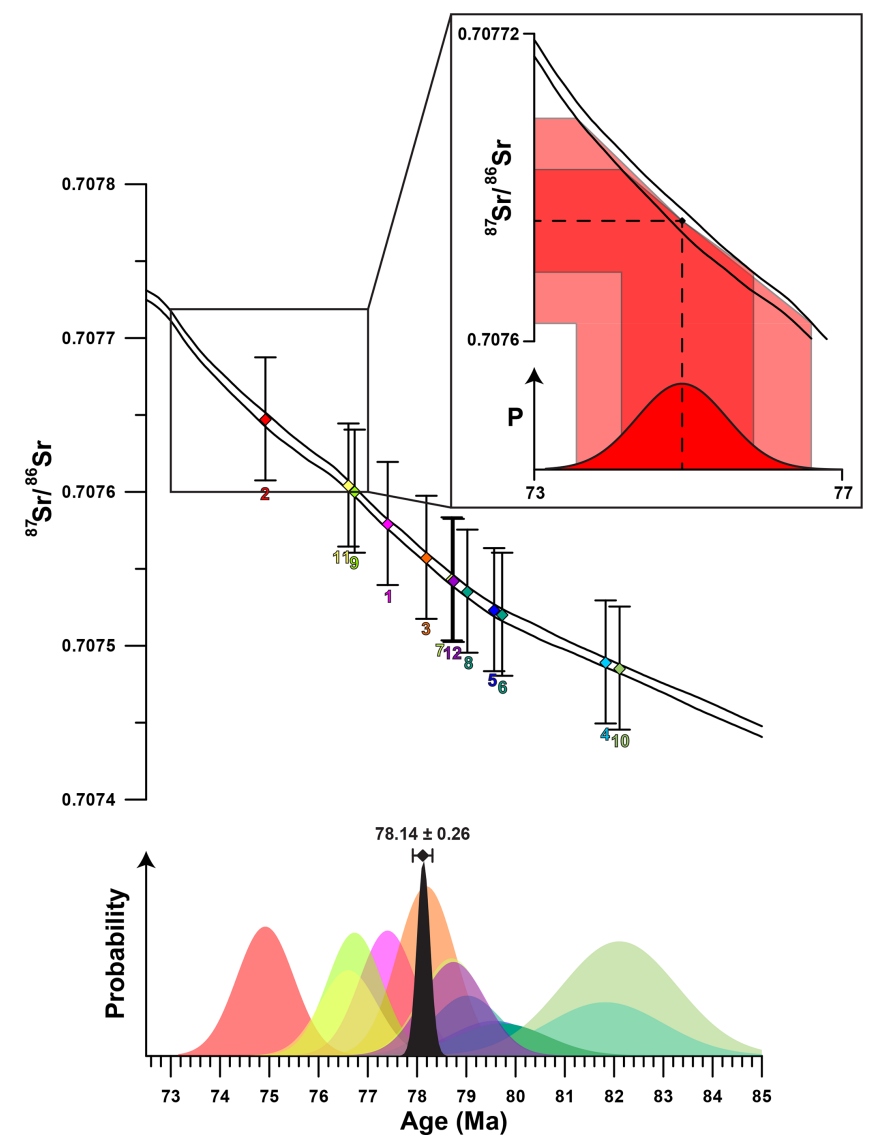

Figure 4. Plot showing the results of Sr-isotopic analyses with error bars $(2 \sigma)$ plotted on the Sr-isotope curve of McArthur et al. (2016; top of image). Numbers below the error bars indicate specimen number. Measurements from the 12 specimens of $R$. diluvianum are represented by parallelograms in different colors which match the probability distributions plotted below. The probability distribution curves in the lower panel show the distribution of uncertainty of each Sr-isotope measurement as well as the uncertainty of the Srisotope curve propagated to the age domain (colors of individual shells are the same as in Fig. 2). Inset shows schematically how uncertainties of the isotope measurements as well as the isotope curve are propagated into the age domain. The black curve shows the total uncertainty distribution function compiled from the 12 individual measurements following Barlow (2004), with the combined age estimate including uncertainty $(2 \sigma)$ shown above.

\subsection{Strontium isotope dating}

$R$. diluvianum specimens were independently dated by comparing ${ }^{87} \mathrm{Sr} /{ }^{86} \mathrm{Sr}$ values measured in the samples with the $\mathrm{Sr}$ isotope curve in the 2016 Geological Timescale (McArthur et al., 2016). Uncertainties in ${ }^{87} \mathrm{Sr} /{ }^{86} \mathrm{Sr}$ measurements were propagated into dates by finding the closest date of the mean ${ }^{87} \mathrm{Sr} /{ }^{86} \mathrm{Sr}$ value as well as the dates of the minimum $(-2 \sigma)$ and maximum $(+2 \sigma){ }^{87} \mathrm{Sr} /{ }^{86} \mathrm{Sr}$ values by linearly interpolating ages in the ${ }^{87} \mathrm{Sr} /{ }^{86} \mathrm{Sr}$ curve matching the measured ${ }^{87} \mathrm{Sr} /{ }^{86} \mathrm{Sr}$ value, including the uncertainty estimated on the 
Sr-isotope curve itself. A composite age for the Ivö Klack deposits was obtained by combining the age uncertainty distributions of the individually dated ${ }^{87} \mathrm{Sr} /{ }^{86} \mathrm{Sr}$ samples into a single age. Due to the non-linear shape of the ${ }^{87} \mathrm{Sr} /{ }^{86} \mathrm{Sr}$ curve, uncertainties of the ${ }^{87} \mathrm{Sr} /{ }^{86} \mathrm{Sr}$ ages were asymmetrical. Since no mathematical solution exists for the combination of asymmetric uncertainties, the asymmetric uncertainty in the total age had to be approximated through maximum likelihood estimation using the combined log likelihood function (Barlow, 2003). The approximation of the total uncertainty of combined ${ }^{87} \mathrm{Sr} /{ }^{86} \mathrm{Sr}$ dating results in this study was carried out using the mathematical approach of Barlow (2004) in R (R Core Team, 2018; Roger Barlow, personal communication, 2019, code available at https://zenodo.org/record/ 1494909, last access: 27 May 2020). The uncertainty interval of the composite age is represented by 2 times the standard error ( $\sim 95.5 \%$ confidence level). A plot of the uncertainty distributions of the individual specimens and the total uncertainty distribution is shown in Fig. 4. Raw ${ }^{87} \mathrm{Sr} /{ }^{86} \mathrm{Sr}$ data are provided in Fig. S8 from de Winter et al. (2020c).

\section{Results}

\subsection{Strontium isotope dating}

Results of strontium isotope analyses are given in Fig. S8 from de Winter et al. (2020c). The mean strontium isotope ratio of all $R$. diluvianum specimens is $0.707552( \pm 0.000112$; $95 \%$ confidence level). The compilation of ${ }^{87} \mathrm{Sr} /{ }^{86} \mathrm{Sr}$ results from 12 specimens of $R$. diluvianum (Fig. 4) shows how age estimates from individual specimens have considerable uncertainties (standard deviations around $1 \mathrm{Myr}$; see Fig. S8 from de Winter et al., 2020c), yet the uncertainty of the composite age is significantly smaller. The composite age for the Ivö Klack deposits is $78.14 \mathrm{Ma}( \pm 0.26$; $95 \%$ confidence level). This result places the age of the Ivö Klack deposits close to the early-late Campanian boundary when applying a 2-fold division of the Campanian and in the middle Campanian when applying a 3-fold division scheme (Ogg et al., 2016). This age estimate is similar to the age obtained when plotting the $B$. mammilatus zone on the recent integration schemes of the Campanian (Wendler, 2013). Earlier estimates (Christensen, 1997; Surlyk and Sørensen, 2010; Sørensen et al., 2015) yielded ages about 2-4 Myr older (80$82 \mathrm{Ma}$ ), but those relied on presently outdated and partly incorrect age models.

\subsection{Shell structure and preservation}

A combination of high-resolution color scans, SEM images and $\mu \mathrm{XRF}$ mapping of shell cross sections reveals that $R$. diluvianum shells consist of thin layers of dark, foliated calcite, interwoven with lighter, more porous carbonate layers (Fig. 3a-e). The latter are characterized by higher concentrations of $\mathrm{Mn}, \mathrm{Fe}$ and $\mathrm{Si}$ and lower $\mathrm{Sr}$ concentrations (Fig. 3f- h). Foliated calcite layers are more densely packed on the inside of the shell, especially in the region of the adductor muscle scar, and at the shell hinge (Fig. 3a). They are characterized by high $\mathrm{Sr}$ concentrations and low concentrations of $\mathrm{Mn}$, Fe and Si (Fig. 3f-h; Fig. S2 from de Winter et al., 2020c). Further away from the shell hinge and the inside of the valve, porous carbonate layers become more dominant. In these regions, $\mu$ XRF mapping also clearly shows that detrital material (high in $\mathrm{Si}$ and $\mathrm{Fe}$ ) is often found between the shell layers (Fig. 3f). SEM images show that the shell structure of $R$. diluvianum strongly resembles that of modern oyster species, as described in previous studies (Fig. 3b-e; Carriker et al., 1979; Surge et al., 2001; Ullmann et al., 2010, 2013; Zimmt et al., 2018). The major part of the shell consists of calcite, of which the foliated structures were sampled for chemical analyses in this study. As in modern oyster species, aragonite may originally have been deposited on the resilium of the shell, but this region is not considered for analyses (see outer tip of shell hinge in Fig. 3a; Stenzel, 1963; Carriker et al., 1979; Sørensen et al., 2012). Close similarities with modern oysters allow the inference that shell growth in $R$. diluvianum occurred in a similar way to modern oyster species like $O s$ trea edulis, Crassostrea virginica and Crassostrea gigas. On this basis we could estimate the total shell height at specific times in ontogeny from microstructural growth markers (purple lines in Fig. 3a; following Zimmt et al., 2018), linking growth to changes in shell chemistry.

\subsection{Trace element results}

The similarity in growth between $R$. diluvianum and modern oyster species is used to assess whether trace element variability in $R$. diluvianum can be interpreted in terms of environmental changes in a similar way to modern oyster shells (e.g., Surge and Lohmann, 2008; Ullmann et al., 2013; Mouchi et al., 2013; Dellinger et al., 2018). The combination of $\mu \mathrm{XRF}$ and LA-ICP-MS analyses on $R$. diluvianum shells resulted in records of changes in $\mathrm{Mg} / \mathrm{Ca}, \mathrm{Sr} / \mathrm{Ca}(\mu \mathrm{XRF})$, $\mathrm{Mg} / \mathrm{Li}$ and $\mathrm{Sr} / \mathrm{Li}$ (LA-ICP-MS) as well as individual concentrations of trace elements such as $\mathrm{Mg}, \mathrm{Mn}, \mathrm{Fe}$ and $\mathrm{Sr}$ (Fig. 5). All chemical analyses were carried out on the dense foliated calcite exposed in cross sections close to the inner edge of the shell valve (Fig. 3a). High-resolution color scans and detailed recording of sampling positions allowed these records to be plotted on a common axis (see Figs. S6, S10 from de Winter et al., 2020c). In Fig. 5, results of chemical analyses of $R$. diluvianum specimens (including diagenetically altered parts) are compared with data from three other mollusk taxa (the belemnite B. mammilatus, the oyster Acutostrea incurva and the radiolithid rudist Biradiolites suecicus) from Ivö Klack (Sørensen et al., 2015) and data from extant oysters (Rucker and Valentine, 1961; Surge et al., 2001; Ullmann et al., 2013). Multi-proxy analysis revealed periodic variations in stable isotope and trace element ratios (see Fig. 6). The amplitudes of these variations plotted 
in Fig. 5 show that $\mathrm{Mg}$ and $\mathrm{Sr}$ concentrations measured in all three fossil bivalve taxa are similar, while concentrations in the belemnite rostra are much higher. Finally, plots in Fig. 5b and $\mathrm{d}$ demonstrate that diagenetic alteration (evident from elevated Mn concentrations) reduces the $\mathrm{Sr}$ concentration in carbonate of all four taxa. Stable oxygen isotope ratios of the shells are affected to a lesser degree (see below). The majority of measurements in all four taxa show very few signs of diagenetic alteration, with most measurements characterized by low ( $\left.<100 \mu \mathrm{g} \mathrm{g}^{-1}\right)$ Mn concentrations (Fig. 5).

\subsection{Stable isotope records}

An overview of stable isotope results of $R$. diluvianum (IRMS, only for shells 1-5; see Fig. 2) compared with the different taxa in Kristianstad Basin and modern oyster data is given in Fig. 5. Stable isotope ratios of the rudist and oyster shells overlap, while belemnite rostra of the species $B$. mammilatus are characterized by much lower $\delta^{13} \mathrm{C}$ and higher $\delta^{18} \mathrm{O}$ values. This suggests that $\delta^{13} \mathrm{C}$ values in belemnite rostra from this species are impacted by vital effects, while heavier $\delta^{18} \mathrm{O}$ values of the belemnites suggest that belemnites lived most of their life away from the coastal environment (in deeper waters), as previously suggested by Sørensen et al. (2015). In contrast, stable isotope ratios recorded in the bivalve shells overlap and match the isotope ratios measured in Campanian chalk deposited in the neighboring Danish Basin (Thibault et al., 2016). Records of $\delta^{13} \mathrm{C}$ and $\delta^{18} \mathrm{O}$ in the growth direction through $R$. diluvianum shells exhibit periodic variations (Fig. 6). These variations are much more regular in $\delta^{18} \mathrm{O}$ records, which show extreme values below $-3 \%$ and up to $0 \%$ VPDB (Fig. 6a). Some shells, such as R. diluvianum 3 (Fig. 7), exhibit longer-term trends on which these periodic variations are superimposed. These trends suggest the presence of multi-annual cyclicity with a period on the order of 10-20 years, but the length of $R$. diluvianum records (max. 10 years) is smaller than the estimated period of these changes and is therefore insufficient to statistically validate the presence of this cyclicity.

The extreme values in $\delta^{18} \mathrm{O}$ records translate into tentative temperatures in the range of extremes of 12 to $26^{\circ} \mathrm{C}$ when assuming a constant $\delta^{18} \mathrm{O}_{\mathrm{sw}}$ value of $-1.0 \%$ (e.g., Thibault et al., 2016) and applying the temperature relationship of Kim and O'Neil (1997). However, the assumption of constant $\delta^{18} \mathrm{O}_{\mathrm{sw}}$ may add bias to the temperature reconstructions, as seawater composition may not have been constant or reflect the marine value year-round in the nearshore Ivö Klack setting. Carbon isotope ratios $\left(\delta^{13} \mathrm{C}\right)$ do not always follow the same trends as $\delta^{18} \mathrm{O}$ records (Fig. 6b). In many parts of $R$. diluvianum shells, there is a clear covariation between the two isotope ratios, suggesting that $\delta^{13} \mathrm{C}$ is affected by seasonal changes. However, in other parts this correlation is less clear, suggesting that other (non-seasonal) factors play a role in determining the $\delta^{13} \mathrm{C}$ of shell material.

\subsection{Age models}

Modeling the growth of $R$. diluvianum bivalves from seasonal variations in $\delta^{18} \mathrm{O}$ profiles yielded age models, growth rate estimates and reconstructions of water temperature variations during the lifetime of the bivalves. Due to the clear seasonal patterns in $\delta^{18} \mathrm{O}$ records (Figs. 6a, 7), modeled $\delta^{18} \mathrm{O}$ profiles closely approximated the measured $\delta^{18} \mathrm{O}$ profiles (total $R^{2}=0.86, N=412$; see Figs. S5 and S9 from de Winter et al., 2020c), lending high confidence to shell age models (see example in Fig. 7). Modeling allowed all proxies measured in the shells of $R$. diluvianum to be plotted against shell age, clearly revealing the influence of seasonal variations in environmental parameters on shell chemistry (Fig. S10 from de Winter et al., 2020c). The age models reveal clear, statistically significant $(p<0.05)$ ontogenetic trends in $\mathrm{Mg} / \mathrm{Li}$, $\mathrm{Sr} / \mathrm{Li}$ and $\delta^{13} \mathrm{C}$ in nearly all specimens of $R$. diluvianum (see Table 1). In three out of five shells, $\delta^{13} \mathrm{C}$ increases with age (see Fig. 6b and Table 1), with ontogenetically older specimens (e.g., $R$. diluvianum no. 2) yielding overall higher $\delta^{13} \mathrm{C}$ values (Fig. 6b). The distribution of slopes of ontogenetic trends in $\mathrm{Li} / \mathrm{Ca}$ cannot be distinguished from random variation. Therefore, no widely shared ontogenetic trends were found for Li proxies in $R$. diluvianum shells.

\section{Discussion}

\subsection{Preservation}

The relative lack of burial and tectonic activity in the Kristianstad Basin has provided ideal circumstances for the nearly immaculate preservation of $R$. diluvianum shells in the Ivö Klack locality (Kominz et al., 2008; Surlyk and Sørensen, 2010). The excellent state of these shells is evident in the preservation of original (porous and foliated) microstructures that closely resemble those reported for several species of modern ostreid shells (Carriker et al., 1979; Surge et al., 2001; Ullmann et al., 2010, 2013; Zimmt et al., 2018; Figs. 2-3). High-magnification SEM images demonstrate the excellent preservation of foliated and vesicular calcite structures in $R$. diluvianum shells (Fig. $3 \mathrm{~b}-\mathrm{d}$ ). The preservation state of $R$. diluvianum shells meets the SEM-based preservation criteria for robust stable isotope analysis set by Cochran et al. (2010). Micro-XRF mapping reveals that the foliated calcite in the shells is characterized by high $\mathrm{Sr}$ concentrations and low concentrations of $\mathrm{Mn}, \mathrm{Fe}$ and $\mathrm{Si}$, elements which are generally associated with diagenetic alteration (e.g., Brand and Veizer, 1980; Al-Aasm and Veizer, 1986a; Immenhauser et al., 2005; Fig. 3b-h). Trends in bulk Mn and Sr concentrations observed in all fossil species from Ivö Klack (Fig. 5b; including less well preserved parts) likely point towards a diagenetic process affecting a less well preserved subset of the data. The lack of covariation between Mn concentration and $\delta^{18} \mathrm{O}$ shows that there is little evidence for meteoric di- 

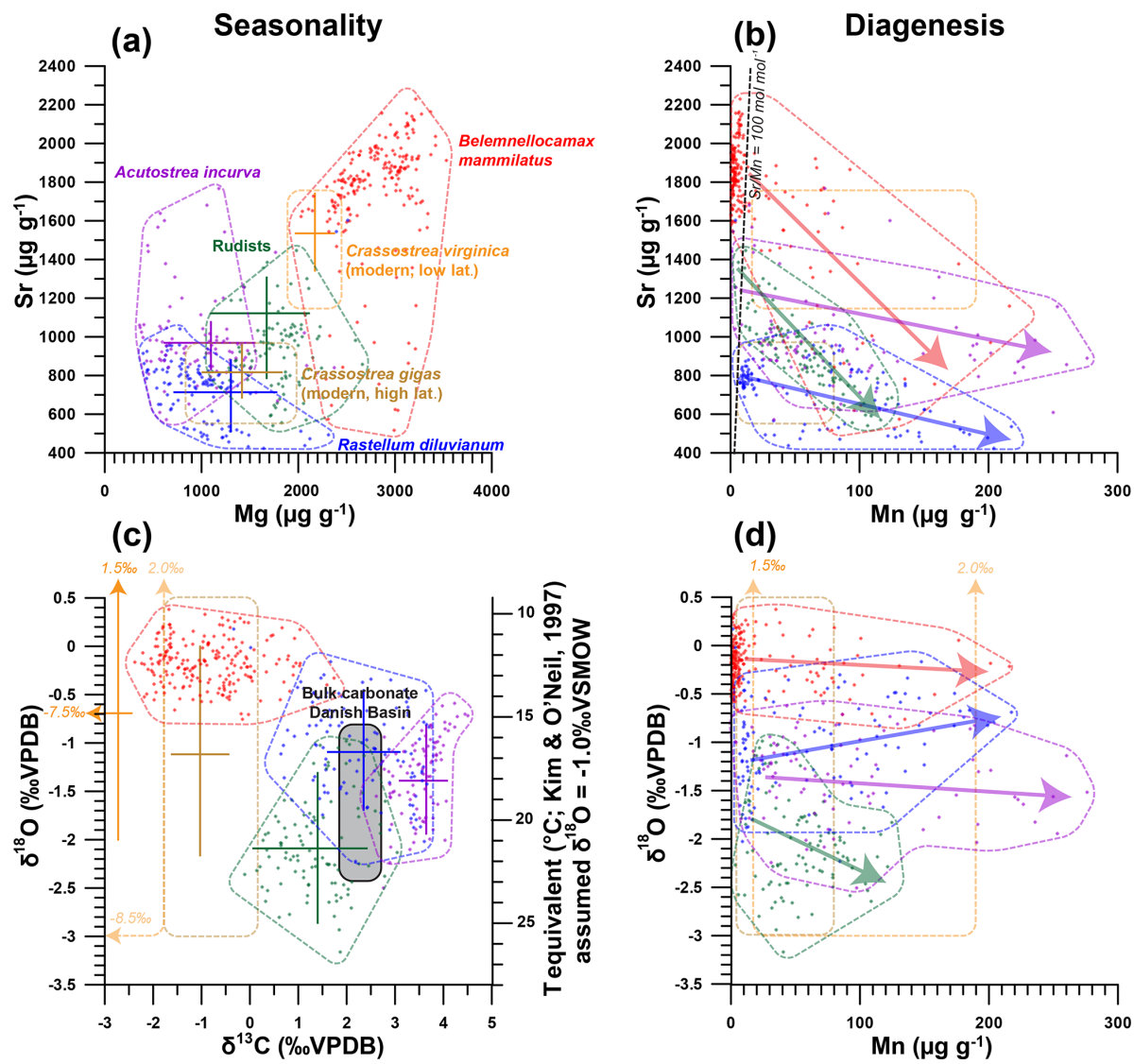

Figure 5. Cross plots summarizing the results of trace element and stable isotope analyses of the oysters $R$. diluvianum (blue), A. incurva (purple), the rudist Biradiolites suecicus (green) and the belemnite B. mammilatus (red; after Sørensen et al., 2015) from the Kristianstad Basin. Results from modern C. gigas (brown; Ullmann et al., 2013) and C. virginica (yellow; Rucker and Valentine, 1961; Surge et al., 2001) oysters are plotted for comparison. Points indicate individual data points; drawn polygons illustrate the range of the data, and crosses indicate the extent of seasonality (if present). (a) Strontium concentrations plotted against magnesium concentrations. (b) Strontium concentrations plotted against manganese concentrations. Arrows indicate the interpreted direction of diagenetic alteration, and the black dashed line shows the $\mathrm{Sr} / \mathrm{Mn}$ diagenesis threshold proposed for belemnite rostra by Sørensen et al. $\left(2015 ; 100 \mathrm{~mol} \mathrm{~mol}^{-1}\right)$. (c) $\delta^{18} \mathrm{O}$ plotted against $\delta^{13} \mathrm{C}$. Grey area indicates the range of stable isotope ratios measured in Campanian chalk deposits from the nearby Danish Basin by Thibault et al. (2016). (d) $\delta^{18} \mathrm{O}$ plotted against manganese concentrations, with arrows indicating proposed direction of diagenetic alteration.

agenesis in these shells (Fig. 5d; Ullmann and Korte, 2015). Instead, these patterns are best explained by early marine cementation of porous carbonate structures from seawater with similar temperature and $\delta^{18} \mathrm{O}$ to the living environment (see also Sørensen et al., 2015).

Typically, a Mn concentration threshold of $100 \mathrm{\mu g} \mathrm{g}^{-1}$ is applied, below which Cretaceous low-magnesium carbonates are assumed to be suitable for chemical analysis (Steuber et al., 2005; Huck et al., 2011). Strontium concentrations above $1000 \mathrm{\mu g} \mathrm{g}^{-1}$ have also been used as markers for good preservation, since diagenetic processes can cause strontium to leach out of carbonates (e.g., Brand and Veizer, 1980; Huck et al., 2011; Ullmann and Korte, 2015). Previous studies of belemnites in Kristianstad Basin proposed a molar $\mathrm{Sr} / \mathrm{Mn}$ threshold of 100 for belemnite rostra (Sørensen et al., 2015). However, the height of thresholds used for diagenetic screening differs widely in the literature due to vari- ation between species, fossil matrices and burial histories (e.g., Veizer, 1983; Steuber et al., 1999; Ullmann and Korte, 2015; de Winter and Claeys, 2016). Applying these thresholds risks introducing biases to chemical datasets from fossil shells and may not be an ideal method for diagenetic screening. Furthermore, large variation in the in vivo incorporation of $\mathrm{Mn}$ and $\mathrm{Sr}$ in mollusk shell carbonate and a strong dependence on the diagenetic setting can make the interpretation of shell preservation from trace element ratios alone highly ambiguous (Ullmann and Korte, 2015). The complex patterns in multi-proxy datasets in this study (Fig. 5) merit great care in applying simple, general thresholds for grouping different processes of carbonate diagenesis. Therefore, in this study, a multi-proxy approach is applied for diagenetic screening in which data are excluded based on a combination of $\mathrm{Si}, \mathrm{Ca}$, $\mathrm{Mn}, \mathrm{Fe}$ and $\mathrm{Sr}$ concentrations; $\delta^{18} \mathrm{O}$ values; and SEM and 
Table 1. Overview of the slopes of ontogenetic trends in $\mathrm{Li} / \mathrm{Ca}$ and $\delta^{13} \mathrm{C}$ records. $p$ values on the bottom of the table show that the distribution of Li/Ca slopes is statistically indistinguishable from random.

\begin{tabular}{|c|c|c|c|c|c|c|}
\hline & \multicolumn{3}{|c|}{$\mathrm{Li} / \mathrm{Ca}$} & \multicolumn{3}{|c|}{$\delta^{13} \mathrm{C}$} \\
\hline & Slope $\left(\mathrm{mol}(\mathrm{mol} \mathrm{yr})^{-1}\right)$ & $R^{2}$ & $p$ value & Slope $\left(\% \circ \mathrm{yr}^{-1}\right)$ & $R^{2}$ & $p$ value \\
\hline R. diluvianum 1 & $-1.29 \times 10^{-6}$ & 0.053 & $4.32 \times 10^{-8}$ & 0.346 & 0.426 & $8.86 \times 10^{-7}$ \\
\hline R. diluvianum 2 & $3.74 \times 10^{-7}$ & 0.101 & $2.68 \times 10^{-5}$ & -0.138 & 0.226 & $6.95 \times 10^{-3}$ \\
\hline R. diluvianum 3 & $3.86 \times 10^{-7}$ & 0.004 & $5.32 \times 10^{-3}$ & 0.169 & 0.440 & $8.19 \times 10^{-8}$ \\
\hline R. diluvianum 4 & $-1.07 \times 10^{-6}$ & 0.025 & $8.78 \times 10^{-4}$ & -0.004 & 0.001 & $8.09 \times 10^{-1}$ \\
\hline R. diluvianum 5 & $-1.94 \times 10^{-6}$ & 0.030 & $6.30 \times 10^{-14}$ & 0.023 & 0.009 & $3.99 \times 10^{-1}$ \\
\hline R. diluvianum 6 & $-2.32 \times 10^{-6}$ & 0.117 & $8.75 \times 10^{-15}$ & 0.136 & 0.492 & $5.53 \times 10^{-11}$ \\
\hline R. diluvianum 7 & $-7.49 \times 10^{-7}$ & 0.029 & $4.77 \times 10^{-2}$ & -0.228 & 0.430 & $2.32 \times 10^{-8}$ \\
\hline R. diluvianum 8 & $-1.19 \times 10^{-7}$ & 0.003 & $2.90 \times 10^{-1}$ & $p\left(\chi^{2}\right)$ & & 1.000 \\
\hline R. diluvianum 9 & $-4.63 \times 10^{-7}$ & 0.010 & $5.65 \times 10^{-2}$ & \multirow{2}{*}{\multicolumn{2}{|c|}{$\begin{array}{c}p\left(\chi^{2}\right) \text { weighed by } R^{2} \\
p\left(\chi^{2}\right) \text { weighed by } p \text { value }\end{array}$}} & 1.000 \\
\hline R. diluvianum 10 & $1.59 \times 10^{-6}$ & 0.015 & $1.61 \times 10^{-2}$ & & & 0.998 \\
\hline R. diluvianum 11 & $-1.87 \times 10^{-6}$ & 0.199 & $4.25 \times 10^{-12}$ & & & \\
\hline \multirow[t]{4}{*}{ R. diluvianum 12} & $-4.55 \times 10^{-7}$ & 0.003 & $4.19 \times 10^{-1}$ & & & \\
\hline & $p\left(\chi^{2}\right)$ & & 0.976 & & & \\
\hline & $p\left(\chi^{2}\right)$ weighed by & & 0.976 & & & \\
\hline & $p\left(\chi^{2}\right)$ weighed by $p$ & & 0.961 & & & \\
\hline
\end{tabular}

visual observations of the shell structure at the location of measurement.

\subsection{Dating the Ivö Klack locality}

While previous attempts at dating Campanian strata mainly focused on relative dating using magneto- and biostratigraphy (Montgomery et al., 1998; Jarvis et al., 2002; Voigt et al., 2010), integration of cyclostratigraphic approaches has recently allowed constraining the age of the Campanian deposits more precisely (Voigt and Schönfield, 2010; Thibault et al., 2012; Wendler, 2013; Thibault et al. 2016). Unfortunately, these rarely cover the time interval in which the Ivö Klack sediments were deposited (e.g., Wendler, 2013; Perdiou et al., 2016). Strontium isotope dating places the Ivö Klack deposits at $78.14 \pm 0.26 \mathrm{Ma}$ (Fig. 4), slightly above the early-late Campanian boundary, while the B. mammilatus biozone is defined as late early Campanian (Wendler, 2013). An influx of radiogenic strontium-rich weathering products from the nearby Transscandinavian Igneous Belt may bias age estimates from strontium isotope ratios (Högdahl et al., 2004). However, studies of modern strontium isotope ratio variability (Palmer and Edmond, 1989) and the potential bias of strontium isotope ratios in shallow-water carbonates (Kuznetsov et al., 2012; El Meknassi et al., 2018) show that the effect of such inputs on strontium isotope dating results is generally negligible, except in semi-confined shallow-marine basins characterized by considerable freshwater input and low salinities $(<7$ psu; psu - practical salinity units). No evidence exists for such exceptional conditions at Ivö Klack (see Sect. 2.1). We therefore conclude that our strontium isotope age estimate, together with biostratigraphic constraints, places the Ivö Klack locality in the earliest late Campanian. The refined dating of the Ivö Klack deposits and fossils allows the results of sclerochronological investigations presented in this work to be placed in the context of longer-term climate reconstructions with improved precision.

\subsection{Trace element variability}

Extracted ranges in seasonal-scale periodic variability in $\mathrm{Mg} / \mathrm{Ca}, \mathrm{Sr} / \mathrm{Ca}, \mathrm{Mg} / \mathrm{Li}$ and $\mathrm{Sr} / \mathrm{Li}$ in all $12 R$. diluvianum shells (Fig. 8) show that interpreting these records in terms of temperature changes is not straightforward. Some of this difficulty arises from the large inter-shell variability in trace element ranges, mostly expressed in strong positive correlations between $\mathrm{Sr} / \mathrm{Li}$ and $\mathrm{Mg} / \mathrm{Ca}\left(R^{2}=0.76\right)$ and between $\mathrm{Sr} / \mathrm{Li}$ and $\mathrm{Mg} / \mathrm{Li}\left(R^{2}=0.93\right)$. The benthic-foraminifera proxy transfer function for $\mathrm{Mg} / \mathrm{Li}$ (Bryan and Marchitto, 2008) does not work for $R$. diluvianum (temperatures $>50^{\circ} \mathrm{C}$ ), presumably due to typically lower $\mathrm{Mg}$ concentrations in foraminifera compared to bivalves (Yoshimura et al., 2011). Bivalve-specific temperature relationships of $\mathrm{Mg} / \mathrm{Ca}$ (Surge and Lohmann, 2008; based on Crassostrea virginica), $\mathrm{Sr} / \mathrm{Li}$ (Füllenbach et al., 2015; based on Cerastoderma edule) and $\mathrm{Mg} / \mathrm{Li}$ (Dellinger et al., 2018; based on Mytilus edulis) yield temperatures in the same range as those reconstructed from stable oxygen isotope measurements $\left(10-20^{\circ} \mathrm{C}\right)$. However, $\mathrm{Sr} / \mathrm{Li}$-based temperature trends are opposite to those based on $\mathrm{Mg}$ proxies, suggesting that they cannot both be applicable to $R$. diluvianum. Poorly constrained changes in seawater chemistry $(\mathrm{Mg} / \mathrm{Ca}$ and $\mathrm{Sr} / \mathrm{Ca}$ ratios of ocean water) also hinder these trace element-based reconstructions (Lear 

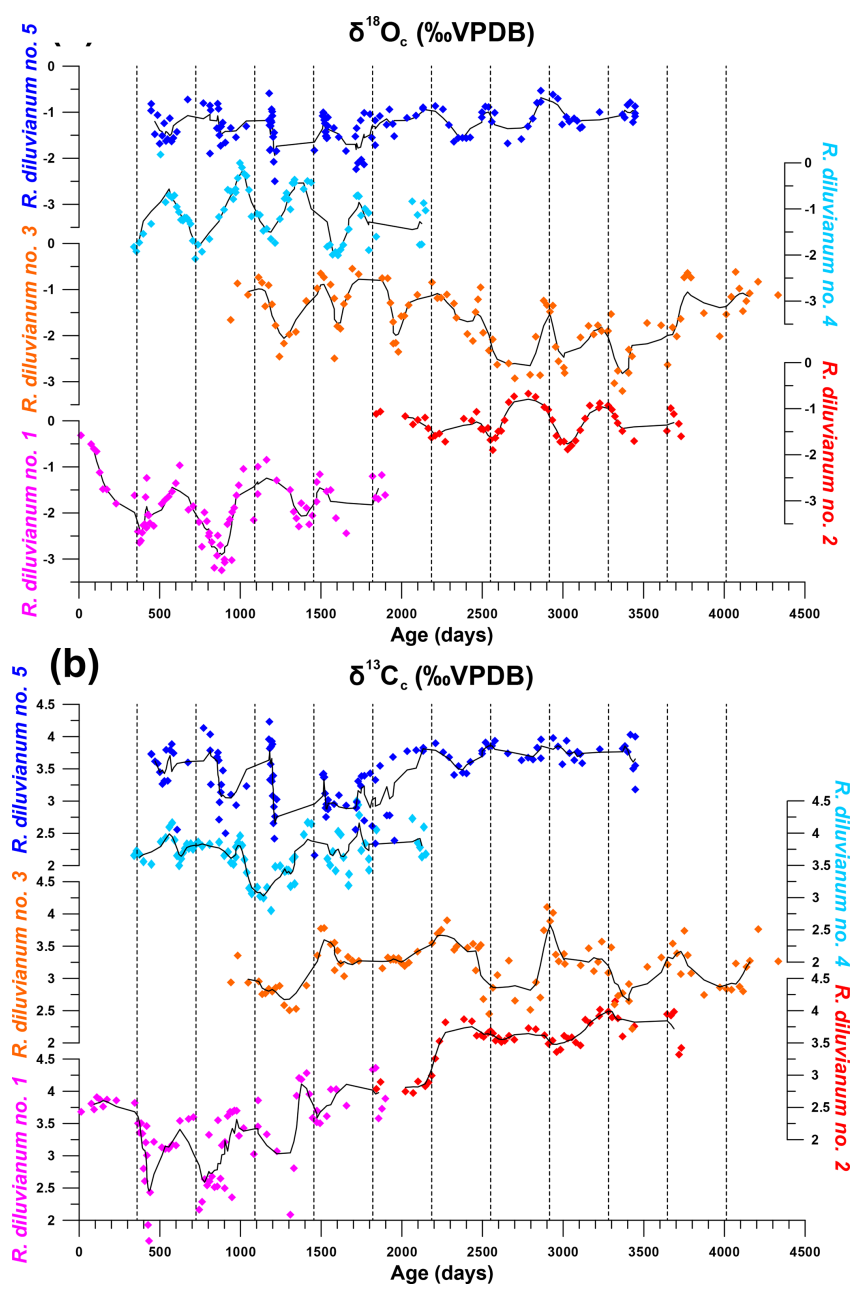

Figure 6. Overview of stable oxygen (a) and carbon (b) profiles from all five shells in which stable isotope profiles were measured and plotted against ontogenetic ages. Black lines indicate five-point running averages through the time series. Vertical dashed lines separate years of growth. All vertical axes of $\delta^{18} \mathrm{O}$ and $\delta^{13} \mathrm{C}$ have the same scale. Color coding is the same as in Fig. 7.

et al., 2003; Coggon et al., 2010; Rausch et al., 2013). The strong $\mathrm{Mg} / \mathrm{Li}-\mathrm{Sr} / \mathrm{Li}$ correlation indicates that both proxies are likely strongly affected by the specimen-specific ontogenetic trends in $\mathrm{Li} / \mathrm{Ca}$ described in Table 1. This, together with the large inter-specimen variability, shows that both Li proxies cannot be used as temperature proxies in $R$. diluvianum. An annual stack of all proxies shows that the positive correlation between $\mathrm{Mg} / \mathrm{Ca}$ and $\delta^{18} \mathrm{O}$ (Fig. 9) is opposite to the temperature relationships found in modern oyster species (Surge and Lohmann, 2008; Mouchi et al., 2013; Ullmann et al., 2013). This, together with the reduced seasonal variability $\left(1.2 \mathrm{mmol} \mathrm{mol}^{-1}\right.$ versus $4-10 \mathrm{mmol} \mathrm{mol}^{-1}$ in modern oysters; Surge and Lohmann, 2008; Mouchi et al., 2013) and the large $\left(>3 \mathrm{mmol} \mathrm{mol}^{-1}\right.$; Fig. 8$)$ inter-specimen variability both in mean value and seasonal $\mathrm{Mg} / \mathrm{Ca}$ range, rules out $\mathrm{Mg} / \mathrm{Ca}$ as a reliable temperature proxy in $R$. diluvianum.

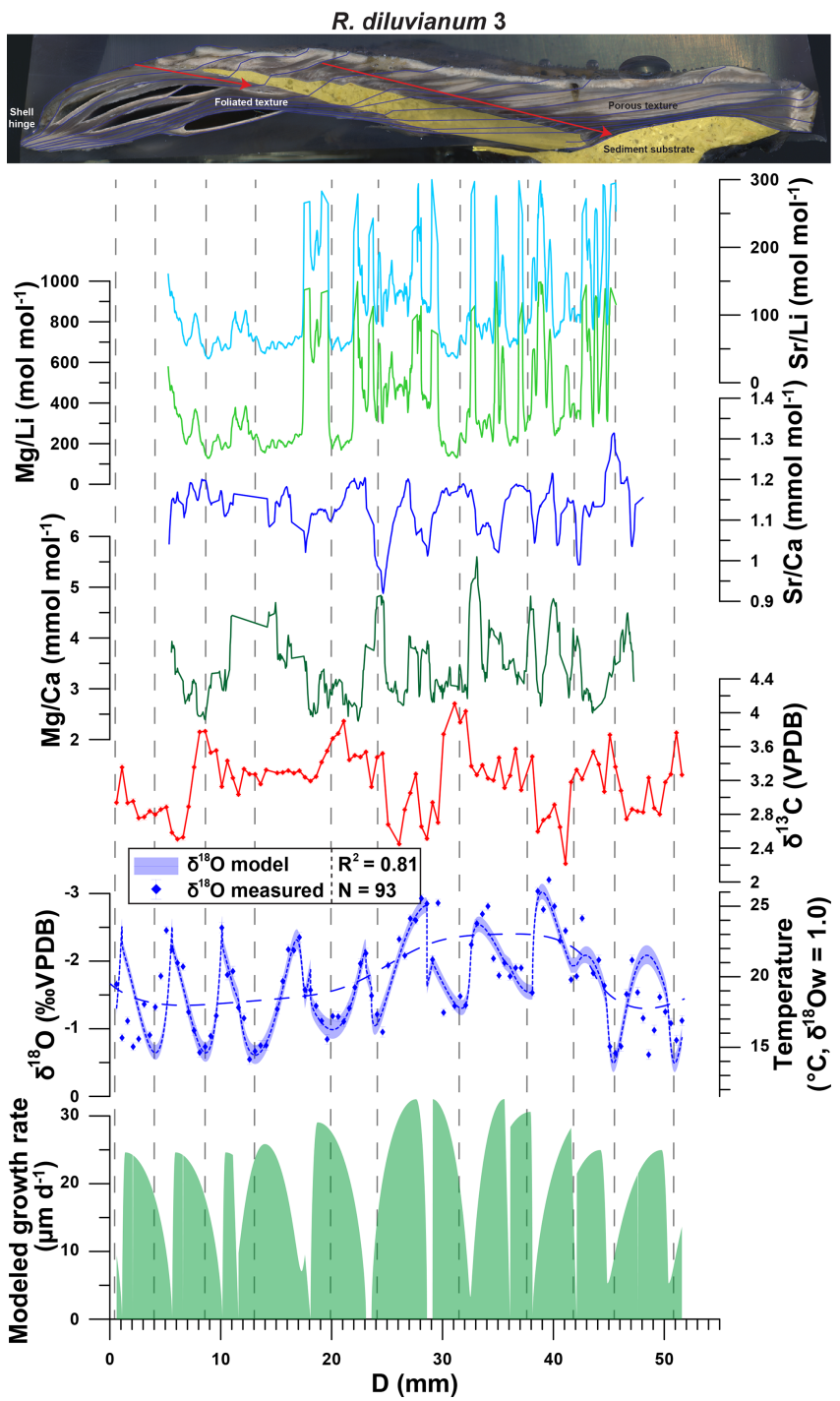

Figure 7. Example of multi-proxy records measured in $R$. diluvianum specimen 3 plotted against distance in growth direction (see image on top and Fig. 3 for reference). From top to bottom, records of $\mathrm{Sr} / \mathrm{Li}$ (light blue), $\mathrm{Mg} / \mathrm{Li}$ (light green), $\mathrm{Sr} / \mathrm{Ca}$ (dark blue), $\mathrm{Mg} / \mathrm{Ca}$ (dark green), $\delta^{13} \mathrm{C}$ (red), $\delta^{18} \mathrm{O}$ (blue dots with error bars) and modeled growth rate (light green shading) are plotted. The shaded blue curve plotted underneath the $\delta^{18} \mathrm{O}$ record illustrates the result of growth and $\delta^{18} \mathrm{O}$ modeling and its propagated error (vertical thickness of curve, $2 \mathrm{SD}$ ). The dashed blue curve plotted on top of the $\delta^{18} \mathrm{O}$ record shows the observed multi-annual trend in the data. Vertical dashed lines separate growth years. Multi-proxy plots for all specimens are given in Fig. S10 from de Winter et al. (2020c).

This result demonstrates that earlier successful attempts to establish calibration curves for $\mathrm{Li}$ - and $\mathrm{Mg}$-based temperature proxies (e.g., Füllenbach et al., 2015; Dellinger et al., 2018) are probably strictly limited to these bivalve species or close relatives. The same conclusion was also drawn by Dellinger et al. (2018) based on $\mathrm{Li} / \mathrm{Mg}$ and $\mathrm{Li}$ isotope ratio measurements in biogenic carbonates. The lack of $\mathrm{Mg} / \mathrm{Li}$ 
or $\mathrm{Sr} / \mathrm{Li}$ calibrations in modern oyster shells limits the interpretation of our results for these element ratios. Establishing such calibrations using modern oysters in cultured experiments may allow these proxies to be used for reconstructions from fossil oyster shells in the future.

While not a promising candidate for reconstructing temperature (Gillikin et al., 2005; Schöne et al., 2013; Ullmann et al., 2013), seasonal $\mathrm{Sr} / \mathrm{Ca}$ fluctuations and relationships between $\mathrm{Sr} / \mathrm{Ca}$ and $\delta^{18} \mathrm{O}$ are consistent between individuals (Figs. 8-9; see also Fig. S6 from de Winter et al., 2020c). This allows $\mathrm{Sr} / \mathrm{Ca}$ ratios to be used together with microstructural observations of growth increments as a basis for seasonal-scale age models in shells for which no $\delta^{18} \mathrm{O}$ measurements were performed. Both mean $\mathrm{Sr} / \mathrm{Ca}$ values and seasonal variability in $R$. diluvianum are consistent with those observed in the same microstructure in modern Crassostrea gigas growing in a similar environment $(0.8$ $1.0 \mathrm{mmol} \mathrm{mol}^{-1}$; Ullmann et al., 2013), suggesting a consistent incorporation of $\mathrm{Sr}$ by different oyster taxa over time. It must be noted that one should be cautious when directly comparing trace element concentrations in biogenic calcite between different time periods, as the seawater composition of Late Cretaceous oceans (e.g., concentrations of $\mathrm{Mg}, \mathrm{Ca}$, $\mathrm{Sr}$ and especially Li) may have been different from that of the present-day ocean (Stanley and Hardie, 1998; Coggon et al., 2010; Rausch et al., 2013). Local enrichments in seawater $\mathrm{Sr}$ concentrations at Ivö Klack driving increased $\mathrm{Sr}$ content in $R$. diluvianum are unlikely, since $\mathrm{Sr} / \mathrm{Ca}$ ratios exhibit only small (2\%-3\%) lateral variability in the world's oceans (De Villiers, 1999). Because $\mathrm{Sr} / \mathrm{Ca}$ ratios in Late Cretaceous oceans were half those of the modern ocean, one would expect that $\mathrm{Sr}$ concentrations in Late Cretaceous biogenic carbonate would be half those in carbonates formed in the modern ocean if the partition coefficient between seawater concentrations and shell concentrations remained constant (Stanley and Hardie, 1998; de Winter et al., 2017a). The fact that this reduction in Sr concentrations relative to the modern ocean is not observed in $R$. diluvianum may mean that there is a physiologically fixed concentration of $\mathrm{Sr}$ in an oyster's shell that is independent of ambient $\mathrm{Sr}$ concentrations.

\subsection{Temperature seasonality}

An annual stack of all $R$. diluvianum proxy records shows a $\delta^{18} \mathrm{O}_{\mathrm{c}}$-based temperature variability in Ivö Klack of 16$21^{\circ} \mathrm{C}$ when assuming a constant $\delta^{18} \mathrm{O}_{\mathrm{sw}}$ of $-1 \%$ VSMOW (Fig. 6). However, comparison with $\delta^{18} \mathrm{O}$ seasonality in individual specimens shows that the annual stack severely dampens seasonality due to small phase shifts in maximum and minimum temperatures, small uncertainties in the age models between years and specimens, and inter-annual differences and longer-term trends in temperature (see Fig. 6). A more accurate estimate of the seasonal extent is obtained by calculating the seasonal range from the coolest winter tem- peratures $\left(12.6^{\circ} \mathrm{C}\right.$ in $R$. diluvianum 4; Fig. 6 and Fig. S10 from de Winter et al., 2020c) with the warmest recorded summer temperature $\left(26^{\circ} \mathrm{C}\right.$ in $R$. diluvianum 1 ; Fig. 6 and Fig. S10 from de Winter et al., 2020c), which yields an extreme maximum seasonal sea surface temperature (SST) range of $\pm 13.4^{\circ} \mathrm{C}$.

A complication of these reconstructions is the assumption of constant $\delta^{18} \mathrm{O}_{\mathrm{sw}}$ of $-1 \%$ VSMOW, which is unlikely to be completely accurate in the nearshore Ivö Klack locality. Comparison with data from Crassostrea gigas growing in a similar nearshore environment (Ullmann et al., 2010; German North Sea coast, $54^{\circ} \mathrm{N}$ ) shows that such an environment away from large river mouths can typically experience seasonal salinity fluctuations of $\sim 4 \mathrm{psu}$, resulting in a dampening of the seasonal $\delta^{18} \mathrm{O}_{\mathrm{c}}$ cycle by $\sim 0.5 \%$ VPDB. Such a salinity effect would reduce our reconstructed $13-26^{\circ} \mathrm{C}$ seasonal temperature range by $\sim 2{ }^{\circ} \mathrm{C}$ to $14-25^{\circ} \mathrm{C}$.

In addition, mean annual $\delta^{18} \mathrm{O}_{\mathrm{sw}}$ values can be considerably lower than the global average seawater composition (e.g., $-1 \%$ to $-1.5 \%$ o VSMOW compared to global ocean mean of $0 \%$ VSMOW in Ullmann et al., 2010). Considering such a deviation would reduce reconstructed temperatures by 4-6 to $10-21^{\circ} \mathrm{C}$, much colder than open marine reconstructions of the Boreal Chalk Sea by Thibault et al. (2016). This result would be in strong disagreement with a recent study by Tagliavento et al. (2019) in which clumped isotope analyses (which do not rely on the assumption of constant $\delta^{18} \mathrm{O}_{\mathrm{sw}}$ ) were used to correct the $\delta^{18} \mathrm{O}_{\mathrm{c}}$-based reconstructions of the boreal chalk and yielded higher temperatures $\left(\sim 26^{\circ} \mathrm{C}\right.$ MAT for open marine SST) and a correction of $\delta^{18} \mathrm{O}_{\mathrm{sw}}$ towards $1 \% o-1.5 \%$ heavier values (resulting in a Campanian $\delta^{18} \mathrm{O}_{\mathrm{sw}}$ of $-0.5 \% \circ-0 \%$ VSMOW). Another caveat is that salinity effects on local $\delta^{18} \mathrm{O}_{\text {sw }}$ strongly depend on the local $\delta^{18} \mathrm{O}_{\text {sw }}$ of the local freshwater source (riverine or precipitation), which in the present-day higher mid-latitudes is around $-7 \%$ VSMOW to $-8 \%$ o VSMOW (e.g., Ullmann et al., 2010), but this is impossible to constrain at Ivö Klack during the Campanian within the scope of this study.

If local $\delta^{18} \mathrm{O}_{\mathrm{sw}}$ values at Ivö Klack were indeed $1 \%$ $1.5 \%$ reduced with respect to those in the fully marine Boreal Chalk Sea, and marine $\delta^{18} \mathrm{O}_{\mathrm{sw}}$ was around $0-0.5 \%$ VSMOW rather than the assumed $-1 \%$ VSMOW, the effects of these two biases cancel each other out, and the best estimation of the extreme seasonal SST range at Ivö Klack based on this study's data would be $14-25^{\circ} \mathrm{C}$ with a MAT of $19^{\circ} \mathrm{C}$. This MAT is comparable to the MAT of the late early Campanian Boreal Chalk Sea waters of $17-19^{\circ} \mathrm{C}$ calculated from coccolith $\delta^{18} \mathrm{O}_{\mathrm{c}}$ (Lowenstam and Epstein, 1954; Jenkyns et al., 2004; Friedrich et al., 2005; Thibault et al., 2016) and slightly warmer than mean annual air temperatures from this paleolatitude based on phosphate- $\delta^{18} \mathrm{O}$ reconstructions $\left( \pm 15^{\circ} \mathrm{C}\right.$; Amiot et al., 2004). However, Ivö Klack SSTs are $\sim 6^{\circ} \mathrm{C}$ colder than the clumped isotope-based reconstructions from marine chalk samples (Tagliavento et al., 2019). The latter could indicate that coastal SSTs and air 


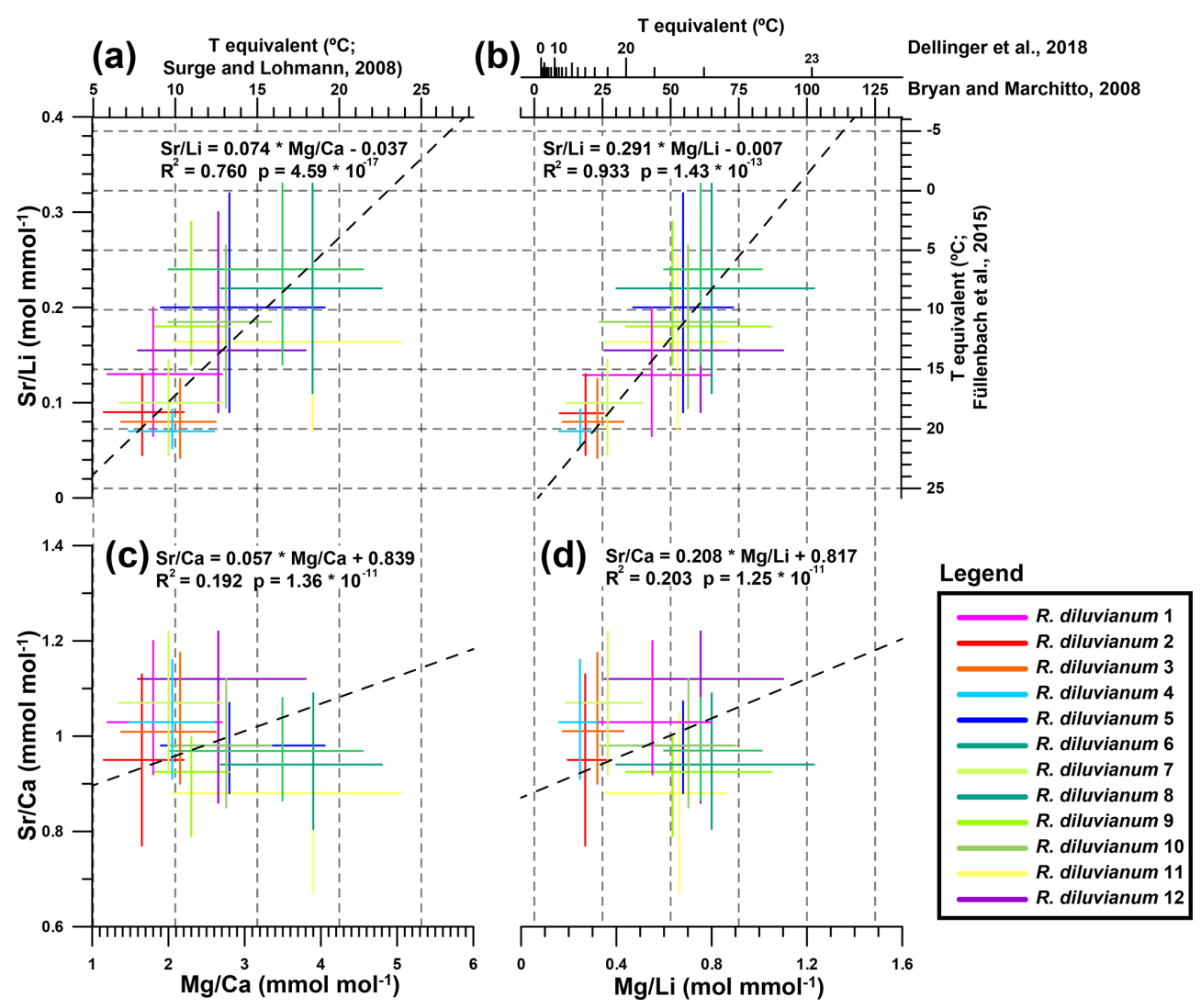

Figure 8. Cross plots showing the extent of interpreted seasonality observed in records of four trace element proxies in all $12 \mathrm{R}$. diluvianum specimens. Colors of lines of individual shells correspond to colors indicated in Fig. 2. Temperature conversions from previously published regressions of the proxies with temperature are shown on opposite axes, with grey dashed lines corresponding to major tick marks on the temperature scale. (a) $\mathrm{Sr} / \mathrm{Li}$ plotted against $\mathrm{Mg} / \mathrm{Ca}$, showing a strong significant intra-shell correlation. (b) $\mathrm{Sr} / \mathrm{Li} \mathrm{plotted} \mathrm{against} \mathrm{Mg} / \mathrm{Li}$, showing a strong significant intra-shell correlation due to dominant variations in Li concentration. Note that two different $\mathrm{Mg} / \mathrm{Li}$ temperature calibrations were explored. (c) $\mathrm{Sr} / \mathrm{Ca}$ plotted against $\mathrm{Mg} / \mathrm{Ca}$, showing weak but significant intra-shell correlation. (d) $\mathrm{Sr} / \mathrm{Ca}$ plotted against $\mathrm{Mg} / \mathrm{Li}$, showing a weakly significant intra-shell correlation. Data for this plot are found in Fig. S13 from de Winter et al. (2020c).

temperatures were much colder than marine temperatures in the Campanian higher latitudes, but such temperature differences are highly unusual compared to modern climates. Alternatively, this difference could highlight a severe temperature bias in (both phosphate and carbonate) $\delta^{18} \mathrm{O}$-based reconstructions, which should be further investigated using independent marine temperature proxies such as the clumped isotope paleothermometer (e.g., de Winter et al., 2018; Tagliavento et al., 2019).

Modeled growth rates in $R$. diluvianum peak near the end of the low-temperature season, and average growth rates are lowest shortly after the temperature maximum (Fig. 9). This phase shift between temperature and growth rate could indicate that growth in $R$. diluvianum in this setting was not limited by low temperatures, as observed in modern mid- to high-latitude oysters (Lartaud et al., 2010). High temperature extremes $\left(>25^{\circ} \mathrm{C}\right)$ may have slowed or stopped growth, as recorded in modern low-latitude settings (Surge et al., 2001). Heat shock has been shown to limit the growth of mod- ern oysters (Crassostrea gigas; Li et al., 2007), although the relatively moderate SST seasonality suggests that very high $\left(>25^{\circ} \mathrm{C}\right)$ temperatures were not common at the Ivö Klack locality (Fig. 6). In this respect it is important to recognize that the use of $\delta^{18} \mathrm{O}$ records from multiple specimens reduces the effects of growth cessations of individuals on seasonal SST reconstructions and allows the full seasonal range in SST to be resolved.

The reconstructed MAT for Ivö Klack is $7-8^{\circ}$ warmer than the present-day seasonal SST range in the North and Baltic seas at similar latitude (e.g., $2-18^{\circ} \mathrm{C}$ monthly seasonality range in Baltic Sea, Karlskrona, Sweden, $56^{\circ} \mathrm{N}$; and $4-18^{\circ} \mathrm{C}$ monthly seasonality range in North Sea, Esbjerg, Denmark, $55^{\circ} \mathrm{N}$; International Research Institute for Climate and Society, 2020). Seasonal SST range at Ivö Klack $\left(11^{\circ} \mathrm{C}\right)$ is significantly lower than the $14-16^{\circ} \mathrm{C}$ maximum seasonal range in temperature that occurs in the present-day Baltic and North seas (International Research Institute for Climate and Society, 2020). Data on temperature seasonality in the 


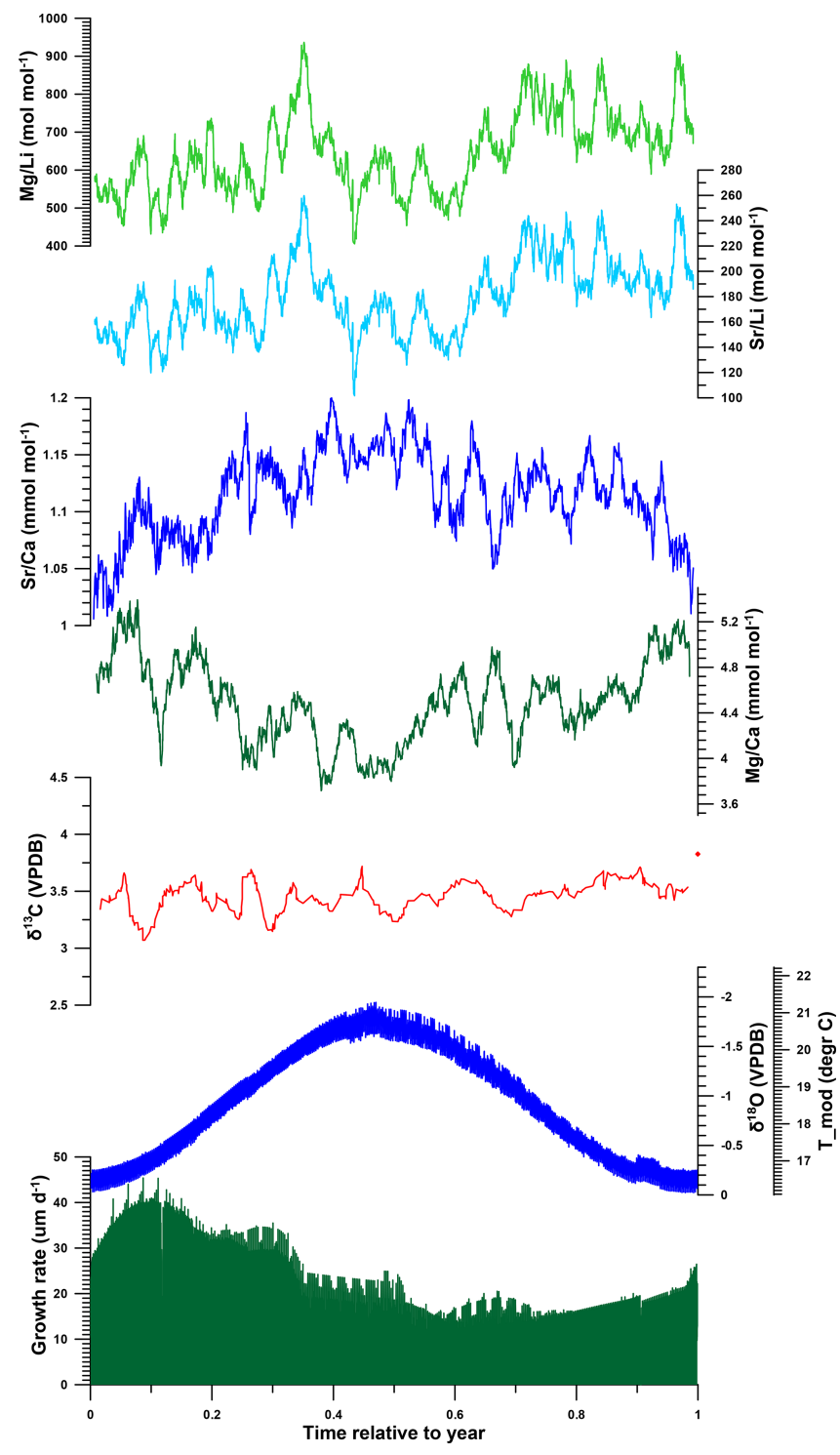

Figure 9. Composite of multi-proxy records from all $R$. diluvianum shells stacked and plotted on a common time axis of 1 year to illustrate the general phase relationships between various proxies in the shells. Records were colored as in Fig. 7. Annual stacks plotted in this figure were produced by applying age models on all multiproxy records, plotting all results against their position relative to the annual cycle and applying 20-point moving averages.

Late Cretaceous are scarce, especially in high-latitude settings. However, comparison with data on Cretaceous temperature seasonality between 15 and $35^{\circ} \mathrm{N}$ paleolatitude (Steuber et al., 2005) shows that while MAT at $50^{\circ} \mathrm{N}$ was significantly lower than at lower latitudes $\left(19\right.$ and $25-30^{\circ} \mathrm{C}$, respectively), the seasonal temperature range during cooler periods in the Late Cretaceous was remarkably similar between latitudes $\left(10-15^{\circ} \mathrm{C}\right.$ in subtropical latitudes vs. $\pm 14^{\circ} \mathrm{C}$ in this study). This observation contrasts with the presentday situation in northern Africa and Europe, in which sea- sonal temperature ranges are generally much higher at midlatitudes to high latitudes $\left(30-50^{\circ} \mathrm{N}\right)$ than at lower latitudes (10-30 N; Prandle and Lane, 1995; Rayner, 2003; Locarnini et al., 2013; NOAA, 2020). Our SST reconstructions also show that Late Cretaceous latitudinal temperature gradients and mid- to high-latitude seasonality were larger than previously assumed based on climate model results (Barrera and Johnson, 1999; Hay and Floegel, 2012; Upchurch et al., 2015).

\subsection{Shell growth and ontogeny}

\subsubsection{Growth curves}

Growth curves of individual $R$. diluvianum specimens clearly converge to a general growth development curve for the species (Fig. 10). Considering that these growth curves are based on $\delta^{18} \mathrm{O}$ and $\mathrm{Sr} / \mathrm{Ca}$ transects in different stages of life in different specimens (large age variation; see Fig. 8), individual growth curves are remarkably similar. The growth of $R$. diluvianum takes the typical shape of the asymptotic von Bertalanffy curve, in which shell height $\left(H_{t}\right)$ development with age $(t)$ is related to a theoretical adult size $H_{\max }$ and a constant $k$ in the equation $H_{t}[\mathrm{~mm}]=H_{\max }$. $\left(1-e^{k \cdot\left(t[\mathrm{yr}]-t_{0}\right)}\right)$, with $t_{0}$ representing the time at which the growth period started (always zero in this case; von Bertalanffy, 1957). When this formula is regressed over all modeled growth data of all shells (1 data point per day, 15146 points in total), the fit with an $H_{\max }$ of $\pm 120.3 \mathrm{~mm}$ and a $k$ value of \pm 0.32 is very good $\left(R^{2}=0.79\right.$; see Fig. 10).

The consistency in growth curves between individuals of $R$. diluvianum is surprising, as modern oyster species are known to exhibit large variations in growth rates and shell shapes as a function of their colonial lifestyle, which often limits the growth of their shells in several directions (Galtsoff, 1964; Palmer and Carriker, 1979). The strong resemblance of growth between individuals and the close fit of the idealized von Bertalanffy growth model suggests that growth of $R$. diluvianum at Ivö Klack was relatively unrestricted in space. This hypothesis is consistent with the apparent mode of life of $R$. diluvianum in Ivö Klack, cemented next to each other in loose groups, subject to strong wave action and turbulence, such that individuals received the same (high) supply of food (Surlyk and Christensen, 1974; Sørensen et al., 2012). The shape of the growth curve of $R$. diluvianum resembles that of modern Chesapeake Bay oysters (Crassostrea virginica), which exhibit a slightly larger modeled maximum height $(150 \mathrm{~mm})$ and a slightly smaller $K$ value (0.28). A larger subset of $R$. diluvianum specimens studied by Sørensen et al. (2012) demonstrates that these bivalves could grow up to $160 \mathrm{~mm}$ in height. The curvature of the growth curve of $R$. diluvianum ( $K$ value) is also similar to that found for other modern shallow-marine bivalve species (e.g., $M a$ coma balthica, $K=0.2-0.4$; Bachelet, 1980; Pinna nobilis, $K=0.33-0.37$; Richardson et al., 2004) and significantly 


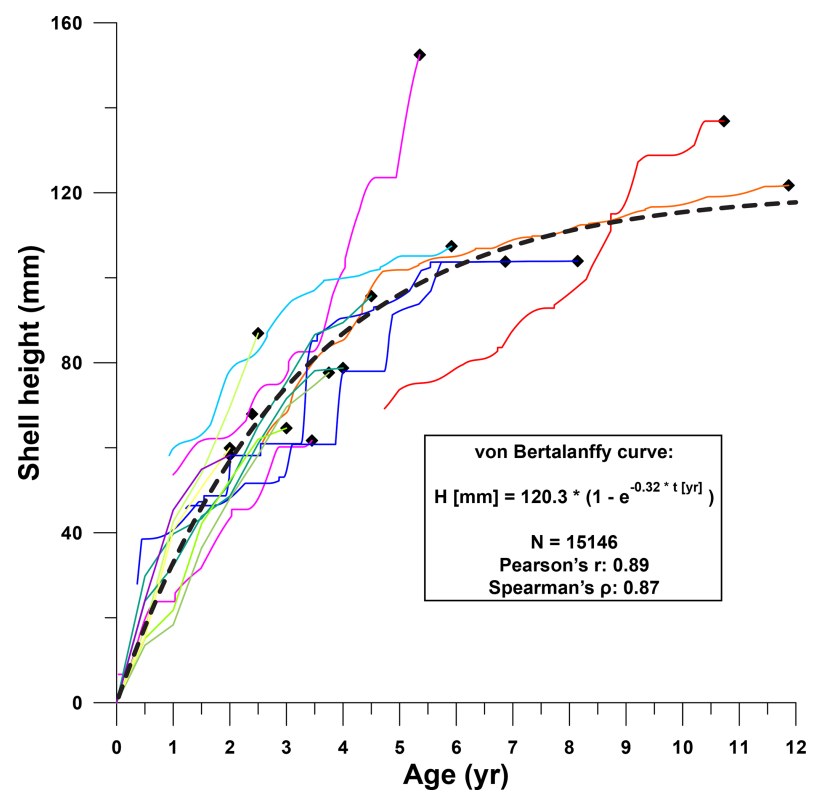

Figure 10. Shell height plotted against age for all $R$. diluvianum records (see Fig. 8 for color legend of lines representing individuals). The similarity between growth curves of different specimens allows a von Bertalanffy curve to be fitted to the data with high confidence. Sinusoidal patterns superimposed on all growth curves are caused by seasonal variability in growth rate (see Figs. 6-7). Data found in Fig. S9 from de Winter et al. (2020c).

higher than in growth curves of deep shelf-dwelling bivalves (e.g., Placopecten magellanicus, $K=0.16-0.24$; MacDonald and Thompson, 1985; Hart and Chute, 2009) or bivalves from cold habitats (e.g., North Atlantic Arctica islandica, $K=0.06$; Strahl et al., 2007). This reflects the high growth rates (steeper growth curves, higher $K$ values) of shallowmarine bivalves compared to species living in less favorable (colder or deeper) habitats, with $R$. diluvianum clearly being part of the former group.

\subsubsection{Seasonal growth}

To study variability in minimum growth temperature (Fig. 11a), length of the growth season and time of year at which maximum growth occurs (Fig. 11b), we isolated individual growth years from all age models of the five shells in which $\delta^{18} \mathrm{O}$ curves were measured (Fig. 11). The onset and end of each growth year correspond to maxima in $\delta^{18} \mathrm{O}$ values (minima in temperatures). The onset of the first growth year in each shell at its precise position relative to the seasonal temperature cycle showed the season in which the individual settled and started growing its shell (Fig. 11b). All data used to create plots in Fig. 11 are provided in Fig. S14 from de Winter et al. (2020c). Relationships between these growth parameters are summarized in Table 2 .

The growing season is shorter than $365 \mathrm{~d}$ in all but 5 modeled years, demonstrating that growth stops or slowdowns

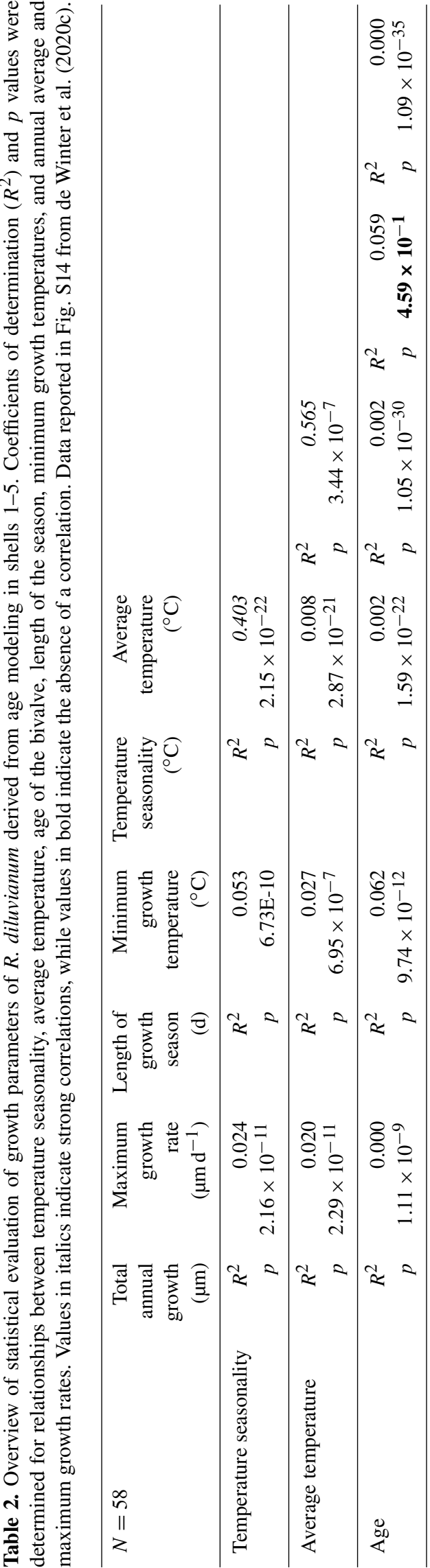

Biogeosciences, 17, 2897-2922, 2020 


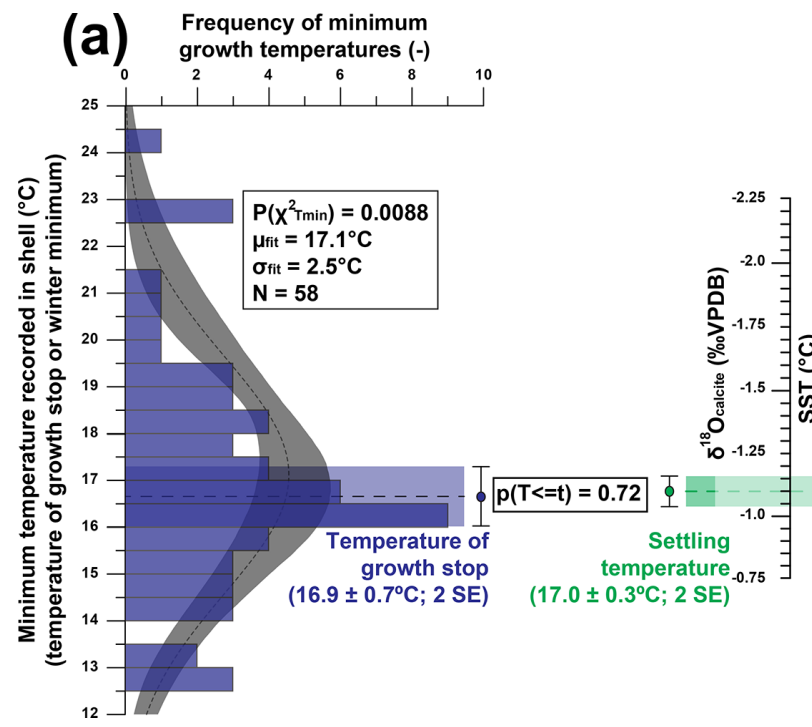

(b)

$P\left(X^{2}\right.$ season of maximum growth $)=0.055 ; N=58$

$r\left(T_{\text {mod }} \sim F_{\text {season of maximum growth })=-0.425}\right.$ (lag $F=1$ month $)$

$\mathrm{p}\left(\mathrm{T}_{\text {mod }} \sim \mathrm{F}_{\text {season of maximum growth }}\right)=8.48^{*} 10^{-8}$ (lag $\mathrm{F}=1$ month)

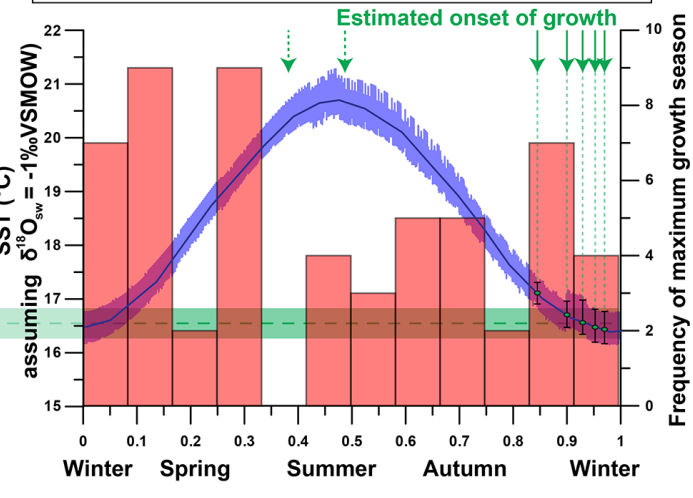

Time of year (relative to $\delta^{18} \mathrm{O}$ cycle)

Figure 11. Overview of statistical evaluation of growth parameters of $R$. diluvianum derived from age modeling in shells 1-5. (a) Histogram of minimum temperatures of growth (equivalent to the time at which growth stops or the minimum yearly temperature) in $R$. diluvianum, showing that the temperature at which growth slows coincides with the time of first growth at post-larval settlement $(p=0.717)$. (b) Histogram of the season of maximum growth relative to the $\delta^{18} \mathrm{O}$ seasonality cycle shows no significant concentration towards a favorable growing season, while moments of first growth (following settlement after the larval stage) are significantly concentrated towards the high$\delta^{18} \mathrm{O}$ season.

did occur in $R$. diluvianum. Minimum growth temperatures (temperatures at which growth stopped) are concentrated around $17^{\circ} \mathrm{C}\left(\chi^{2}=0.0088\right.$; Fig. 11a) and correlate strongly to MAT $\left(R^{2}=0.57\right.$; Table 2$)$, suggesting that growth halts in $R$. diluvianum were not forced by an absolute temperature threshold but rather by timing relative to the seasonality (circadian rhythm). If there had been a fixed temperature threshold (e.g., $6^{\circ} \mathrm{C}$ or $10^{\circ} \mathrm{C}$ for Crassostrea gigas; Lartaud et al., 2010; Ullmann et al., 2010) the length of the growth season would have positively correlated with annual mean temperature, but this is not the case $\left(R^{2}<0.1\right)$. Other authors have suggested that growth in modern $C$. gigas does not actually cease completely but rather slows down significantly, which may also have been the case in $R$. diluvianum. On average, the moment of minimum growth in $R$. diluvianum occurs right after the highest temperatures of the year are reached (early autumn; Fig. 9).

The season of first growth (after larval stage) is concentrated in the 2 last months before the $\delta^{18} \mathrm{O}$ maximum (first half of winter), when modeled water temperatures are $\pm 17^{\circ} \mathrm{C}$ (Fig. 11b). Note that only three of the five shells allowed sampling of the first month of growth, and extrapolated records for the other two shells are likely unreliable. Comparing Fig. 11a and Fig. 11b shows that growth halts and settling occur at similar temperatures $(16.9 \pm 0.7$ and $17.0 \pm 0.3^{\circ} \mathrm{C}$, respectively; $p=0.72$ ), suggesting that these events occur simultaneously or on either side of a seasonal growth halt (if it occurs). The timing of spawning and settling in $R$. diluvianum differs from that in modern oysters, which generally spawn during the spring season, with the young oyster spat settling in the summer (e.g., for Crassostrea gigas: Fan et al., 2011). If the larval stage of $R$. diluvianum lasted as long, this would put the spawning season of $R$. diluvianum in summer. In the case of modern oysters, it is known that reproduction requires a relatively warm minimum temperature (ideally around $22^{\circ} \mathrm{C}$ for $C$. gigas; Cognie et al., 2006) and that a combination of salinity and temperature conditions is important (Fan et al., 2011), while extreme temperatures $\left(>28^{\circ} \mathrm{C}\right.$; Surge et al., 2001) can induce shock. Similar temperature conditions occurred at Ivö Klack in summer, possibly explaining the delay of the spawning season of R. diluvianum.

Figure $11 \mathrm{~b}$ shows that the distribution of months with fastest growth rate is random $\left(p\left(\chi^{2}\right)=0.055,<95 \%\right.$ confidence). However, in 27 of the 58 years, the growth peak occurs in the season with decreasing $\delta^{18} \mathrm{O}$ values ("spring season"). Table 2 shows that the extent of temperature seasonality (difference between minimum and maximum $\delta^{18} \mathrm{O}$ converted to temperature) significantly influences the length of the growing season $\left(R^{2}=0.40\right)$. However, total annual growth and maximum growth rates are independent of SST (both seasonal range and MAT), and ontogenetic age of the organism does not predict a significant part of any of the above-mentioned growth and seasonality parameters (Table 2). If temperature controlled the growth of $R$. diluvianum shells, larger temperature seasonality would increase the chance of crossing thresholds of temperature tolerance, which would shorten the length of the growing season. All 
this suggests that temperature seasonality may not have been the dominant factor causing growth cessations in $R$. diluvianum. This hypothesis is supported by the observation that temperatures at which growth cessations occur $(16.9 \pm$ $0.7^{\circ} \mathrm{C}$; Fig. 11a) show large variability and do not correspond significantly to the lowest temperatures of the year. A possible explanation might be that these growth cessations occurred in response to attempted predation or extreme weather events, which are not necessarily paced to the seasonal cycle.

These observations do not necessarily show that $R$. diluvianum tolerated larger temperature differences than modern oyster taxa because the extent of seasonality $\left(14-25^{\circ} \mathrm{C}\right)$ causes neither the lower $\left(\sim 10^{\circ} \mathrm{C}\right)$ nor the upper $\left(\sim 28^{\circ} \mathrm{C}\right)$ temperature limit between which shell growth occurs in modern oysters to be reached. If temperature tolerance of $R$. diluvianum did resemble that of its closest modern relatives, then the mild seasonal temperatures at Ivö Klack might have provided the ideal temperature range for its growth. Perhaps these favorable conditions partly explain why biodiversity and abundance of invertebrates at Ivö Klack were so high (Surlyk and Sørensen, 2010).

\subsubsection{Productivity}

Shell growth in $R$. diluvianum may not have been governed by temperature but rather by changes in productivity. The observation that peak growth rates and settling both occur during the early spring or late autumn season (before or after the growth cessation; Fig. 11b) supports this hypothesis. Spring or autumn productivity blooms caused by increases in nutrient-rich fresh water from onshore (Arthur et al., 1983; Krantz et al., 1987) or storm-induced mixing of more nutrient-rich deeper waters are common in presentday mid- and high-latitude marine ecosystems (e.g., Waniek, 2003; Danielsson et al., 2008). An increase in seasonal freshwater influx would cause longer growth cessations to occur in the spring season, reducing the length of the growing season while also dampening the temperature seasonality reconstructed from $\delta^{18} \mathrm{O}$ due to the influx of isotopically light fresh water which dampens the seasonal cycle (see Sect. 5.5.2). This explains the correlation found between these two parameters (Table 2). At the same time, this freshwater input would increase reconstructed MAT by increasing $\delta^{18} \mathrm{O}$ values in $R$. diluvianum shells, explaining the weak positive correlation between MAT and length of the growing season (Table 2).

The occurrence of spring blooms is supported by weak $0.5 \%-1.0 \%$ seasonal variability in $\delta^{13} \mathrm{C}$ (Fig. 6). Seasonal changes in productivity and/or salinity will cause changes in DIC in the environment, which are apparent in the $\delta^{13} \mathrm{C}$ of the shell above the ontogenetic trends and the effect of respiration on $\delta^{13} \mathrm{C}$ (see Sect. 2.4; Table 1). The fact that a clear seasonality in $\delta^{13} \mathrm{C}$ is absent from the stack in Fig. 9 shows that these productivity peaks do not occur at regular times of the year and that their effect on $\delta^{13} \mathrm{C}$ is obscured by ontogenetic trends. The $0.5 \% 0-1.0 \%$ o shifts in $\delta^{13} \mathrm{C}$ that appear to be seasonal are much smaller than those in modern oyster records (2\%o-3\%o in low-latitude estuarine Crassostrea virginica; Surge et al., 2001, 2003; Surge and Lohmann, 2008). Instead, the determined shifts more closely resemble the $0.5 \%$ variability in $\delta^{13} \mathrm{C}$ observed in modern Crassostrea gigas from the same approximate latitude as Ivö Klack in the North Sea (Ullmann et al., 2013). The extreme isotopic shifts in the estuarine $C$. virginica specimens have been shown to be caused by large shifts in freshwater input due to large seasonal variations in rainfall over southern North America (Surge et al., 2003), while smaller variations in C. gigas from the North Sea are produced by DIC changes due to seasonal changes in productivity (e.g., spring blooms; Ullmann et al., 2013), indirect effects of temperature variability (Chauvaud et al., 2011) and changes in food source (Marchais et al., 2015). The closer resemblance of $R$. diluvianum to the North Sea condition shows that the Ivö Klack paleoenvironment did not experience large seasonal shifts in freshwater input and may have seen productivity peaks in spring season. The latter interpretation is in agreement with the coincidence of negative $\delta^{13} \mathrm{C}$ excursions (in parts of the records not affected by ontogenetic trends and respiration), with the high- $\delta^{18} \mathrm{O}$ season (winter or spring; Fig. 6 and Fig. S6 from de Winter et al., $2020 \mathrm{c}$ ), the settling of larvae and the onset of shell growth, and a peak in growth rates in the spring season (much like in wild modern oysters; Berthelin et al., 2000; Figs. 9, 11a).

\subsubsection{Ontogeny}

A part of the variation in $\delta^{13} \mathrm{C}$ is explained by the presence of ontogenetic trends. These trends are known to occur in marine and freshwater bivalves, including bivalves with symbionts (Klein et al., 1996b; Watanabe et al., 2004; Gillikin et al., 2007; McConnaughey and Gillikin, 2008). The scale and direction of the trends in $\delta^{13} \mathrm{C}$ are not consistent between individual $R$. diluvianum shells, which is also the case in other bivalve species (see Sect. 4.5; Table 1; McConnaughey and Gillikin, 2008, and references therein). Studies of modern bivalves show that in larger (older) bivalves, the contribution of respired $\mathrm{CO}_{2}$ to carbon in the shell is larger (up to $40 \%$; Gillikin et al., 2007). This finding explains common trends of reducing $\delta^{13} \mathrm{C}$ with age in bivalve shells, since respired carbon is isotopically lighter than environmental DIC. Since ontogenetic trends are likely caused by changes in the amount of respired carbon entering the shell, but the direction of these trends is inconsistent in $R$. diluvianum, the contribution of respired $\mathrm{CO}_{2}$ to $R$. diluvianum shells likely did not strictly increase with age. While this complicates the interpretation of $\delta^{13} \mathrm{C}$ records, the relative contribution of environmental changes to $\delta^{13} \mathrm{C}$ variability in $R$. diluvianum shells does appear to be highest at the positive end of the ontogenetic trend. 


\section{Conclusions}

The highly biodiverse marine invertebrate community at Ivö Klack in the Kristianstad Basin in southern Sweden offers a unique opportunity to recover a wealth of information about Campanian climate and environment in high latitudes and the ecology and life of extinct invertebrate species that lived under these conditions. The lack of burial and tectonic activity in the region favored Rastellum diluvianum fossil shells from Ivö Klack that were well preserved, as is evident from the excellent preservation of growth structures typical for ostreid shells as well as from the limited evidence for geochemical changes associated with diagenetic alteration. This excellent preservation allows the shells of $R$. diluvianum to be used to accurately and precisely constrain the age of the Ivö Klack locality using strontium isotope stratigraphy $\left(78.14 \pm 0.26 \mathrm{Ma} ;{ }^{87} \mathrm{Sr} /{ }^{86} \mathrm{Sr}=0.707552 \pm 0.000112\right)$. Furthermore, $R$. diluvianum shells reveal sub-annual-scale variability in temperature, local environment and growth rates through a multi-proxy geochemical approach. The combination of trace element and stable isotope measurements with growth modeling based on $\delta^{18} \mathrm{O}$ records in the shells allows all measured proxies to be aligned on the same time axis. Application of transfer functions for potential $\mathrm{Mg} / \mathrm{Ca}$, $\mathrm{Mg} / \mathrm{Li}$ and $\mathrm{Sr} / \mathrm{Li}$ temperature proxies established in modern invertebrates yields temperatures consistent with those calculated from $\delta^{18} \mathrm{O}$ records. However, close examination of the seasonal-phase relationships between these proxies reveals that the sub-annual variability in these trace element ratios is not controlled by temperature changes alone. This observation supports previous studies that found the expression of trace element proxies to be highly variable among species and even among different specimens of the same species. If trace element proxies are to be used for seasonality reconstructions in pre-Quaternary times, a more robust, non-species-specific model for the incorporation of trace elements by bivalves is required. Establishing such a model requires culture experiments with different bivalve species in which multiple parameters influencing trace element composition can be controlled (e.g., temperature, salinity, food intake and microstructure).

Stable isotope records in $R$. diluvianum shells reveal a MAT of $19^{\circ} \mathrm{C}$ with a seasonal water temperature range of $\pm 11^{\circ} \mathrm{C}\left(14-25^{\circ} \mathrm{C}\right)$ at Ivö Klack. This value for MAT is lower than full marine SST of Boreal Chalk, recently re-evaluated with the clumped isotope thermometer. The difference highlights potential biases in temperature reconstructions based on $\delta^{18} \mathrm{O}$ values and argues for re-evaluations of these proxy records with more accurate techniques such as clumped isotope analysis. Comparing the seasonal temperature range reconstructed from $R$. diluvianum shells with other Late Cretaceous seasonality records from lower latitudes reveals that both latitudinal gradients and SST seasonality outside the tropics were much higher than predicted by climate models. This disagreement between data and models clearly illus- trates the need for more data on Late Cretaceous seasonality outside the (sub-)tropical latitudes and highlights how important such proxy-based reconstructions are for improving our understanding of the dynamics in temperature variability in both space and time during greenhouse climates.

Finally, the coupled modeling and multi-proxy approach applied in this study sheds light on the effects of environmental changes on the life cycle and sub-annual growth of $R$. diluvianum shells. This study reveals that growth curves of $R$. diluvianum strongly resemble those in modern shallowmarine bivalves that grow in coastal high-latitude environments. However, ontogenetic changes in growth rate of our boreal oysters seem unrelated to temperature, in contrast to modern, high-latitude oysters that tend to lower their growth rate and cease mineralization below a certain cold threshold. We conclude that growth cessations and sub-annual changes in growth rate in $R$. diluvianum were most likely not caused by intolerable temperatures but rather by the circadian rhythm tied to the seasonal cycle and seasonal changes in sea surface productivity, driven by nutrient-rich freshwater inputs.

Data availability. The data used in this paper are stored in the open-access online database Zenodo and can be accessed using the following link: https://doi.org/10.5281/zenodo.2581304 (de Winter et al., 2020c). The description of the supplementary figures can be found under the Supplement link.

Supplement. The supplement related to this article is available online at: https://doi.org/10.5194/bg-17-2897-2020-supplement.

Author contributions. The study was designed by NJdW and NT. CVU, AMS and NT provided samples. NJdW carried out trace element analyses with the help of SGod and SJMVM. CS assisted NJdW with strontium isotope analyses. SGoo assisted NJdW with SEM imaging. FV and PC provided support for obtaining the funding necessary for this study. The initial draft of the paper was written by NJdW, with the help of CVU, NT, SGod and SGoo. All authors assisted in the writing and review process.

Competing interests. The authors declare that they have no conflict of interest.

Acknowledgements. The authors would like to thank Johan Vellekoop and Andrew Johnson for their review, which helped improve the paper, as well as the editor, Aninda Mazumdar, for guiding the review process. This work was made possible with help of an IWT doctoral fellowship (grant no. IWT700) and FWO postdoctoral grant (grant no. 12ZB220N) awarded to Niels J. de Winter. Niels J. de Winter and Philippe Claeys also acknowledge funding by the VUB Strategic Research grant. Instrumentation at the VUB was funded by Hercules infrastructure grants (grant nos. HERC09 
and HERC46). The authors acknowledge financial and logistic support from the Flemish Research Foundation (FWO; research project G017217N) and Teledyne CETAC Technologies (Omaha, NE, USA) as well as support from VUB Strategic Research. Stijn Goolaerts is funded by a Belspo BRAIN project (grant no. BR/175/A2/CHICXULUB). Nicolas Thibault is funded by Carlsbergfondet (grant no. CF16-0457). The authors would like to thank David Verstraeten for his help with stable isotope analyses. We thank Bart Lippens for assisting sample preparation and Joke Belza for help with the LA-ICP-MS analyses. Thanks are due to Julien Cilis (RBINS) for his assistance with SEM imaging. The authors wish to thank Emily Judd for discussions about her growth rate model for bivalve shells and Roger Barlow for his assistance in handling strontium isotope measurements with asymmetric error distributions.

Financial support. This research has been supported by the Flemish Institute for Science and Technology (IWT) (grant no. IWT700), the FWO postdoctoral grant (no. 12ZB220N), the Hercules Infrastructure grant (nos. HERC09 and HERC46), the FWO infrastructure grant (no. G017217N), the Belspo BRAIN Project (grant no. BR/175/A2/CHICXULUB), the Carlsbergfondet (grant no. CF160457), and the VUB Strategic Research.

Review statement. This paper was edited by Aninda Mazumdar and reviewed by Andrew Johnson, Johan Vellekoop, and two anonymous referees.

\section{References}

Al-Aasm, I. S. and Veizer, J.: Diagenetic stabilization of aragonite and low-Mg calcite, II. Stable isotopes in rudists, J. Sediment. Res., 56, 763-770, 1986a.

Al-Aasm, I. S. and Veizer, J.: Diagenetic stabilization of aragonite and low-Mg calcite, I. Trace elements in rudists, J. Sediment. Res., 56, 138-152, 1986b.

Alberti, M., Fürsich, F. T., Abdelhady, A. A., and Andersen, N.: Middle to Late Jurassic equatorial seawater temperatures and latitudinal temperature gradients based on stable isotopes of brachiopods and oysters from Gebel Maghara, Egypt, Palaeogeogr. Palaeocl., 468, 301-313, https://doi.org/10.1016/j.palaeo.2016.11.052, 2017.

Amiot, R., Lécuyer, C., Buffetaut, E., Fluteau, F., Legendre, S., and Martineau, F.: Latitudinal temperature gradient during the Cretaceous Upper Campanian-Middle Maastrichtian: $\delta^{18} \mathrm{O}$ record of continental vertebrates, Earth Planet. Sc. Lett., 226, 255-272, https://doi.org/10.1016/j.epsl.2004.07.015, 2004.

Andreasson, F. P. and Schmitz, B.: Winter and summer temperatures of the early middle Eocene of France from Turritella $\delta^{18} \mathrm{O}$ profiles, Geology, 4, 1067-1070, 1996.

Arthur, M. A., Williams, D. F., and Jones, D. S.: Seasonal temperature-salinity changes and thermocline development in the mid-Atlantic Bight as recorded by the isotopic composition of bivalves, Geology, 11, 655-659, https://doi.org/10.1130/00917613(1983)11<655:STCATD>2.0.CO;2, 1983.
Bachelet, G.: Growth and recruitment of the tellinid bivalve Macoma balthica at the southern limit of its geographical distribution, the Gironde estuary (SW France), Mar. Biol., 59, 105-117, 1980.

Barlow, R.: Asymmetric systematic errors, arXiv [preprint], arXiv:0306138, 18 June 2003.

Barrera, E. and Johnson, C. C.: Evolution of the Cretaceous Oceanclimate System, Geol. Soc. Am., 332, 1-419, 1999.

Berthelin, C., Kellner, K., and Mathieu, M.: Storage metabolism in the Pacific oyster (Crassostrea gigas) in relation to summer mortalities and reproductive cycle (West Coast of France), Comp Biochem. Phys. B, 125, 359-369, https://doi.org/10.1016/S03050491(99)00187-X, 2000.

Brand, U. and Veizer, J.: Chemical diagenesis of a multicomponent carbonate system - 1: Trace elements, J. Sediment. Res. 50, 1219-1236, 1980.

Brand, U. and Veizer, J.: Chemical diagenesis of a multicomponent carbonate system-2: stable isotopes, J. Sediment. Res., 51, 987997, 1981.

Bryan, S. P. and Marchitto, T. M.: $\mathrm{Mg} / \mathrm{Ca}$ - temperature proxy in benthic foraminifera: New calibrations from the Florida Straits and a hypothesis regarding $\mathrm{Mg} / \mathrm{Li}$, Paleoceanography, 23, PA2220, https://doi.org/10.1029/2007PA001553, 2008.

Burgener, L., Hyland, E., Huntington, K. W., Kelson, J. R., and Sewall, J. O.: Revisiting the equable climate problem during the Late Cretaceous greenhouse using paleosol carbonate clumped isotope temperatures from the Campanian of the Western Interior Basin, USA, Palaeogeogr., Palaeocl., 516, 244-267, https://doi.org/10.1016/j.palaeo.2018.12.004, 2018.

Butler, P. G., Wanamaker, A. D., Scourse, J. D., Richardson, C. A., and Reynolds, D. J.: Variability of marine climate on the North Icelandic Shelf in a 1357year proxy archive based on growth increments in the bivalve Arctica islandica, Palaeogeogr. Palaeocl., 373, 141-151, https://doi.org/10.1016/j.palaeo.2012.01.016, 2013.

Carriker, M. R., Palmer, R. E., and Prezant, R. S.: Functional ultramorphology of the dissoconch valves of the oyster Crassostrea virginica, in: Proceedings of the National Shellfisheries Association, Vol. 70, 139-183, 1979.

Carriker, M. R., Swann, C. P., Prezant, R. S., and Counts, C. L.: Chemical elements in the aragonitic and calcitic microstructural groups of shell of the oysterCrassostrea virginica: A proton probe study, Mar. Biol., 109, 287-297, 1991.

Chauvaud, L., Thébault, J., Clavier, J., Lorrain, A., and Strand, Ø.: What's Hiding Behind Ontogenetic $\delta^{13} \mathrm{C}$ Variations in Mollusk Shells? New Insights from the Great Scallop (Pecten maximus), Estuar. Coast., 34, 211-220, https://doi.org/10.1007/s12237010-9267-4, 2011.

Christensen, W. K.: Upper Cretaceous belemnites from the Kristianstad area in Scania, Fossils and Strata, 7, 1-70, 1975.

Christensen, W. K.: The Albian to Maastrichtian of southern Sweden and Bornholm, Denmark: a review, Cretaceous Res., 5, 313327, 1984.

Christensen, W. K.: Paleobiogeography and migration in the Late Cretaceous belemnite family Belemnitellidae, Acta Palaeontol. Pol., 42, 457-495, 1997.

Clarke, L. J. and Jenkyns, H. C.: New oxygen isotope evidence for long-term Cretaceous climatic change in the Southern Hemisphere, Geology, 27, 699-702, 1999. 
Cochran, J. K., Kallenberg, K., Landman, N. H., Harries, P. J., Weinreb, D., Turekian, K. K., Beck, A. J., and Cobban, W. A.: Effect of diagenesis on the $\mathrm{Sr}, \mathrm{O}$, and $\mathrm{C}$ isotope composition of late Cretaceous mollusks from the Western Interior Seaway of North America, Am. J. Sci., 310, 69-88, https://doi.org/10.2475/02.2010.01, 2010.

Coggon, R. M., Teagle, D. A., Smith-Duque, C. E., Alt, J. C., and Cooper, M. J.: Reconstructing past seawater $\mathrm{Mg} / \mathrm{Ca}$ and $\mathrm{Sr} / \mathrm{Ca}$ from mid-ocean ridge flank calcium carbonate veins, Science, 327, 1114-1117, 2010.

Cognie, B., Haure, J., and Barillé, L.: Spatial distribution in a temperate coastal ecosystem of the wild stock of the farmed oyster Crassostrea gigas (Thunberg), Aquaculture, 259, 249-259, 2006.

Csiki-Sava, Z., Buffetaut, E., Ôsi, A., Pereda-Suberbiola, X., and Brusatte, S. L.: Island life in the Cretaceous - faunal composition, biogeography, evolution, and extinction of land-living vertebrates on the Late Cretaceous European archipelago, Zookeys, 469, 1-161, https://doi.org/10.3897/zookeys.469.8439, 2015.

Dalbeck, P., England, J., Cusack, M., Lee, M. R., and Fallick, A. E.: Crystallography and chemistry of the calcium carbonate polymorph switch in M. edulis shells, Eur. J. Mineral., 18, 601-609, https://doi.org/10.1127/0935-1221/2006/0018-0601, 2006.

Danielsson, Å., Papush, L., and Rahm, L.: Alterations in nutrient limitations - scenarios of a changing Baltic Sea, J. Mar. Syst., 73, 263-283, 2008.

DeConto, R. M., Hay, W. W., Thompson, S. L., and Bergengren, J.: Late Cretaceous climate and vegetation interactions: cold continental interior paradox, Special Papers-Geological Society Of America, 332, 391-406, 1999.

De Villiers, S.: Seawater strontium and $\mathrm{Sr} / \mathrm{Ca}$ variability in the Atlantic and Pacific oceans, Earth Planet. Sc. Lett., 171, 623-634, 1999.

Dellinger, M., West, A. J., Paris, G., Adkins, J. F., von Strandmann, P. A. P., Ullmann, C. V., Eagle, R. A., Freitas, P., Bagard, M.-L., and Ries, J. B.: The Li isotope composition of marine biogenic carbonates: Patterns and Mechanisms, Geochim. Cosmochim. Ac., 236, 315-335, 2018.

de Winter, N. J. and Claeys, P.: Micro X-ray fluorescence ( $\mu \mathrm{XRF}$ ) line scanning on Cretaceous rudist bivalves: A new method for reproducible trace element profiles in bivalve calcite, edited by: Petrizzo, M. R., Sedimentology, 64, 231-251, https://doi.org/10.1111/sed.12299, 2016.

de Winter, N. J., Sinnesael, M., Makarona, C., Vansteenberge, S., and Claeys, P.: Trace element analyses of carbonates using portable and micro-X-ray fluorescence: performance and optimization of measurement parameters and strategies, J. Anal. Atom. Spectr., 32, 1211-1223, $2017 \mathrm{~b}$.

de Winter, N. J., Goderis, S., Dehairs, F., Jagt, J. W., Fraaije, R. H., Van Malderen, S. J., Vanhaecke, F., and Claeys, P.: Tropical seasonality in the late Campanian (late Cretaceous): Comparison between multiproxy records from three bivalve taxa from Oman, Palaeogeogr. Palaeocl., 485, 740-760, 2017a.

de Winter, N. J., Vellekoop, J., Vorsselmans, R., Golreihan, A., Soete, J., Petersen, S. V., Meyer, K. W., Casadio, S., Speijer, R. P., and Claeys, P.: An assessment of latest Cretaceous Pycnodonte vesicularis (Lamarck, 1806) shells as records for palaeoseasonality: a multi-proxy investigation, Clim. Past, 14, 725-749, https://doi.org/10.5194/cp-14-725-2018, 2018. de Winter, N. J., Goderis, S., Malderen, S. J. M. V., Sinnesael, M., Vansteenberge, S., Snoeck, C., Belza, J., Vanhaecke, F., and Claeys, P.: Subdaily-Scale Chemical Variability in a Torreites Sanchezi Rudist Shell: Implications for Rudist Paleobiology and the Cretaceous Day-Night Cycle, Paleoceanogr. Paleocl., 35, PA003723, https://doi.org/10.1029/2019PA003723, 2020a.

de Winter, N. J., Vellekoop, J., Clark, A. J., Stassen, P., Speijer, R. P., and Claeys, P.: The giant marine gastropod Campanile giganteum (Lamarck, 1804) as a high-resolution archive of seasonality in the Eocene greenhouse world, Geochem. Geophy., Geosy., 21, GC008794, https://doi.org/10.1029/2019GC008794, 2020b.

de Winter, N. J., Ullmann, C. V., Sorensen, A. M., Thibault, N., Goderis, S., Van Malderen, S. J. M., Snoeck, C., Goolaerts, S., Vanhaecke, F., and Claeys, P.: Supplement to: Shell chemistry of the Boreal Campanian bivalve Rastellum diluvianum (Linnaeus, 1767) reveals temperature seasonality, growth rates and life cycle of an extinct Cretaceous oyster, Zenodo, https://doi.org/10.5281/zenodo.2581304, 2020c.

Donnadieu, Y., Pucéat, E., Moiroud, M., Guillocheau, F., and Deconinck, J.-F.: A better-ventilated ocean triggered by Late Cretaceous changes in continental configuration, Nat. Commun., 7, 10316, https://doi.org/10.1038/ncomms10316, 2016.

El Meknassi, S., Dera, G., Cardone, T., De Rafélis, M., Brahmi, C., and Chavagnac, $\mathrm{V}$.: $\mathrm{Sr}$ isotope ratios of modern carbonate shells: Good and bad news for chemostratigraphy, Geology, 46, 10031006, 2018.

Fan, C., Koeniger, P., Wang, H., and Frechen, M.: Ligamental increments of the mid-Holocene Pacific oyster Crassostrea gigas are reliable independent proxies for seasonality in the western Bohai Sea, China, Palaeogeogr. Palaeocl., 299, 437-448, 2011.

Freitas, P. S., Clarke, L. J., Kennedy, H. A., and Richardson, C. A.: Inter- and intra-specimen variability masks reliable temperature control on shell $\mathrm{Mg} / \mathrm{Ca}$ ratios in laboratory- and field-cultured Mytilus edulis and Pecten maximus (bivalvia), Biogeosciences, 5, 1245-1258, https://doi.org/10.5194/bg-5-1245-2008, 2008.

Friedrich, O., Herrle, J. O., and Hemleben, C.: Climatic changes in the late Campanian - early Maastrichtian: Micropaleontological and stable isotopic evidence from an epicontinental sea, J. Foramin. Res., 35, 228-247, 2005.

Friedrich, O., Herrle, J. O., Wilson, P. A., Cooper, M. J., Erbacher, J., and Hemleben, C.: Early Maastrichtian carbon cycle perturbation and cooling event: Implications from the South Atlantic Ocean, Paleoceanography, 24, PA2211, https://doi.org/10.1029/2008PA001654, 2009.

Friedrich, O., Norris, R. D., and Erbacher, J.: Evolution of middle to Late Cretaceous oceans-a 55 my record of Earth's temperature and carbon cycle, Geology, 40, 107-110, 2012.

Füllenbach, C. S., Schöne, B. R., and Mertz-Kraus, R.: Strontium/lithium ratio in aragonitic shells of Cerastoderma edule (Bivalvia) - A new potential temperature proxy for brackish environments, Chem. Geol., 417, 341-355, 2015.

Galtsoff, P. S.: The American Oyster: US Fish and Wildlife Service, Fish. Bull., 64, 480, 1964.

Gillikin, D. P., Lorrain, A., Navez, J., Taylor, J. W., André, L., Keppens, E., Baeyens, W., and Dehairs, F.: Strong biological controls on $\mathrm{Sr} / \mathrm{Ca}$ ratios in aragonitic marine bivalve shells, Geochem. Geophy. Geosy., 6, Q05009, https://doi.org/10.1029/2004GC000874, 2005. 
Gillikin, D. P., Lorrain, A., Bouillon, S., Willenz, P. and Dehairs, F.: Stable carbon isotopic composition of Mytilus edulis shells: relation to metabolism, salinity, $\delta^{13} \mathrm{C}$ DIC and phytoplankton, Organic Geochemistry, 37, 1371-1382, 2006.

Gillikin, D. P., Lorrain, A., Meng, L., and Dehairs, F.: A large metabolic carbon contribution to the $\delta^{13} \mathrm{C}$ record in marine aragonitic bivalve shells, Geochim. Cosmochim. Ac., 71, 2936-2946, 2007

Goodwin, D. H., Flessa, K. W., Schone, B. R., and Dettman, D. L.: Cross-calibration of daily growth increments, stable isotope variation, and temperature in the Gulf of California bivalve mollusk Chione cortezi: implications for paleoenvironmental analysis, Palaios, 16, 387-398, 2001.

Grossman, E. L. and Ku, T.-L.: Oxygen and carbon isotope fractionation in biogenic aragonite: temperature effects, Chemical Geology: Isotope Geoscience section, 59, 59-74, 1986.

Hart, D. R. and Chute, A. S.: Verification of Atlantic sea scallop (Placopecten magellanicus) shell growth rings by tracking cohorts in fishery closed areas, Can. J. Fish. Aquat. Sci., 66, 751758,2009

Hay, W. W. and Floegel, S.: New thoughts about the Cretaceous climate and oceans, Earth-Sci. Rev., 115, 262-272, 2012.

Högdahl, K., Andersson, U. B., and Eklund, O.: The Transscandinavian Igneous Belt (TIB) in Sweden: a review of its character and evolution, Geol. Surv. Finland Espoo, 37, 1-25, 2004.

Huber, B. T., Norris, R. D., and MacLeod, K. G.: Deep-sea paleotemperature record of extreme warmth during the Cretaceous, Geology, 30, 123-126, 2002.

Huck, S., Heimhofer, U., Rameil, N., Bodin, S., and Immenhauser, A.: Strontium and carbon-isotope chronostratigraphy of Barremian-Aptian shoal-water carbonates: Northern Tethyan platform drowning predates OAE 1a, Earth Planet. Sc. Lett., 304, 547-558, https://doi.org/10.1016/j.epsl.2011.02.031, 2011.

Huyghe, D., Lartaud, F., Emmanuel, L., Merle, D., and Renard, M.: Palaeogene climate evolution in the Paris Basin from oxygen stable isotope $\left(\delta^{18} \mathrm{O}\right)$ compositions of marine molluscs, $\mathrm{J}$. Geol. Soc., 172, 576-587, 2015.

Huyghe, D., de Rafelis, M., Ropert, M., Mouchi, V., Emmanuel, L., Renard, M., and Lartaud, F.: New insights into oyster high-resolution hinge growth patterns, Mar. Biol., 166, 1-17, https://doi.org/10.1007/s00227-019-3496-2, 2019.

Immenhauser, A., Nägler, T. F., Steuber, T., and Hippler, D.: A critical assessment of mollusk ${ }^{18} \mathrm{O} /{ }^{16} \mathrm{O}, \mathrm{Mg} / \mathrm{Ca}$, and ${ }^{44} \mathrm{Ca} /{ }^{40} \mathrm{Ca}$ ratios as proxies for Cretaceous seawater temperature seasonality, Palaeogeogr. Palaeocl., 215, 221-237, 2005.

International Research Institute for Climate and Society: IRI/LDEO Climate Data Library, available at: http://iridl.ldeo.columbia.edu, last access: 6 March 2020.

IPCC: IPCC, 2013: Climate Change 2013: The Physical Science Basis, Contribution of Working Group I to the Fifth Assessment Report of the Intergovernmental Panel on Climate Change, Cambridge Univ. Press, Cambridge, UK, and New York, 1535 pp., 2013

Ivany, L. C.: Reconstructing paleoseasonality from accretionary skeletal carbonates - challenges and opportunities, Paleontological Society Papers, 18, 133-166, 2012.

Ivany, L. C. and Runnegar, B.: Early Permian seasonality from bivalve $\delta^{18} \mathrm{O}$ and implications for the oxygen isotopic composition of seawater, Geology, 38, 1027-1030, 2010.
Jablonski, D., Huang, S., Roy, K., and Valentine, J. W.: Shaping the latitudinal diversity gradient: new perspectives from a synthesis of paleobiology and biogeography, Am. Nat., 189, 1-12, 2017.

Jarvis, I., Mabrouk, A., Moody, R. T., and de Cabrera, S.: Late Cretaceous (Campanian) carbon isotope events, sea-level change and correlation of the Tethyan and Boreal realms, Palaeogeogr. Palaeocl., 188, 215-248, 2002.

Jenkyns, H. C., Gale, A. S., and Corfield, R. M.: Carbon-and oxygen-isotope stratigraphy of the English Chalk and Italian Scaglia and its palaeoclimatic significance, Geol. Mag., 131, 134, 1994.

Jenkyns, H. C., Forster, A., Schouten, S., and Damsté, J. S. S.: High temperatures in the late Cretaceous Arctic Ocean, Nature, 432, 888-892, 2004.

Jones, D. S.: Sclerochronology: reading the record of the molluscan shell: annual growth increments in the shells of bivalve molluscs record marine climatic changes and reveal surprising longevity, Am. Sci., 71, 384-391, 1983.

Judd, E. J., Wilkinson, B. H., and Ivany, L. C.: The life and time of clams: Derivation of intra-annual growth rates from highresolution oxygen isotope profiles, Palaeogeogr. Palaeocl., 490, 70-83, 2018.

Kawaguchi, T. and Watabe, N.: The organic matrices of the shell of the American oyster Crassostrea virginica Gmelin, J. Exp. Mar. Biol. Ecol., 170, 11-28, https://doi.org/10.1016/00220981(93)90126-9, 1993.

Kim, S.-T. and O'Neil, J. R.: Equilibrium and nonequilibrium oxygen isotope effects in synthetic carbonates, Geochim. Cosmochim. Ac., 61, 3461-3475, 1997.

Klein, R. T., Lohmann, K. C., and Thayer, C. W.: Bivalve skeletons record sea-surface temperature and $\delta^{18} \mathrm{O}$ via $\mathrm{Mg} / \mathrm{Ca}$ and ${ }^{18} \mathrm{O} /{ }^{16} \mathrm{O}$ ratios, Geology, 24, 415-418, 1996a.

Klein, R. T., Lohmann, K. C., and Thayer, C. W.: SrCa and $13 \mathrm{C} 12 \mathrm{C}$ ratios in skeletal calcite of Mytilus trossulus: Covariation with metabolic rate, salinity, and carbon isotopic composition of seawater, Geochim. Cosmochim. Ac., 60, 4207-4221, https://doi.org/10.1016/S0016-7037(96)00232-3, 1996b.

Kominz, M. A., Browning, J. V., Miller, K. G., Sugarman, P. J., Mizintseva, S., and Scotese, C. R.: Late Cretaceous to Miocene sea-level estimates from the New Jersey and Delaware coastal plain coreholes: an error analysis, Basin Res., 20, 211-226, 2008.

Krantz, D. E., Williams, D. F., and Jones, D. S.: Ecological and paleoenvironmental information using stable isotope profiles from living and fossil molluscs, Palaeogeogr. Palaeocl., 58, 249-266, https://doi.org/10.1016/0031-0182(87)90064-2, 1987.

Kuznetsov, A. B., Semikhatov, M. A., and Gorokhov, I. M.: The $\mathrm{Sr}$ isotope composition of the world ocean, marginal and inland seas: Implications for the $\mathrm{Sr}$ isotope stratigraphy, Stratigr. Geol. Correl., 20, 501-515, https://doi.org/10.1134/S0869593812060044, 2012.

Lartaud, F., Emmanuel, L., De Rafélis, M., Ropert, M., Labourdette, N., Richardson, C. A., and Renard, M.: A latitudinal gradient of seasonal temperature variation recorded in oyster shells from the coastal waters of France and The Netherlands, Facies, 56, 13-25, 2010.

Lear, C. H., Elderfield, H., and Wilson, P. A.: A Cenozoic seawater $\mathrm{Sr} / \mathrm{Ca}$ record from benthic foraminiferal calcite and its application in determining global weathering fluxes, Earth 
Planet. Sc. Lett., 208, 69-84, https://doi.org/10.1016/S0012821X(02)01156-1, 2003.

Li, Y., Qin, J. G., Abbott, C. A., Li, X., and Benkendorff, K.: Synergistic impacts of heat shock and spawning on the physiology and immune health of Crassostrea gigas: an explanation for summer mortality in Pacific oysters, Am. J. Physiol.-Reg. I., 293, R2353R2362, 2007.

Locarnini, R. A., Mishonov, A. V., Antonov, J. I., Boyer, T. P., Garcia, H. E., Baranova, O. K., Zweng, M. M., Paver, C. R., Reagan, J. R., Johnson, D. R., Hamilton, M., and Seidov, D.: World ocean atlas 2013. Volume 1, Temperature, U.S. Department of Commerce, National Oceanic and Atmospheric Administration, National Environmental Satellite, Data and Information Service, https://doi.org/10.7289/v55x26vd, 2013.

Lorrain, A., Paulet, Y.-M., Chauvaud, L., Dunbar, R., Mucciarone, D., and Fontugne, M.: $\delta^{13} \mathrm{C}$ variation in scallop shells: increasing metabolic carbon contribution with body size?, Geochim. Cosmochim. Ac., 68, 3509-3519, 2004.

Lorrain, A., Gillikin, D. P., Paulet, Y.-M., Chauvaud, L., Le Mercier, A., Navez, J., and André, L.: Strong kinetic effects on $\mathrm{Sr} / \mathrm{Ca}$ ratios in the calcitic bivalve Pecten maximus, Geology, 33, 965968, 2005.

Lowenstam, H. A. and Epstein, S.: Paleotemperatures of the postAptian Cretaceous as determined by the oxygen isotope method, J. Geol., 62, 207-248, 1954.

MacDonald, B. A. and Thompson, R. J.: Influence of temperature and food availability on the ecological energetics of the giant scallop Placopecten magellanicus, I. Growth rates of shell and somatic tissue, Marine ecology progress series, Oldendorf, 25, 279-294, 1985.

Marchais, V., Richard, J., Jolivet, A., Flye-Sainte-Marie, J., Thébault, J., Jean, F., Richard, P., Paulet, Y.-M., Clavier, J., and Chauvaud, L.: Coupling experimental and field-based approaches to decipher carbon sources in the shell of the great scallop, Pecten maximus (L.), Geochim. . Cosmochim. Ac., 168, 5869, https://doi.org/10.1016/j.gca.2015.07.010, 2015.

McArthur, J. M., Howarth, R. J., and Bailey, T. R.: Strontium Isotope Stratigraphy: LOWESS Version 3: Best Fit to the Marine Sr-Isotope Curve for 0-509 Ma and Accompanying Lookup Table for Deriving Numerical Age, J. Geol., 109, 155-170, https://doi.org/10.1086/319243, 2001.

McArthur, J. M., Steuber, T., Page, K. N., and Landman, N. H.: Srisotope stratigraphy: assigning time in the Campanian, Pliensbachian, Toarcian, and Valanginian, J. Geol., 124, 569-586, 2016.

McConnaughey, T. A.: Sub-equilibrium oxygen-18 and carbon-13 levels in biological carbonates: carbonate and kinetic models, Coral Reefs, 22, 316-327, 2003.

McConnaughey, T. A. and Gillikin, D. P.: Carbon isotopes in mollusk shell carbonates, Geo-Mar. Lett., 28 287-299, https://doi.org/10.1007/s00367-008-0116-4, 2008.

McConnaughey, T. A., Burdett, J., Whelan, J. F., and Paull, C. K.: Carbon isotopes in biological carbonates: respiration and photosynthesis, Geochim. Cosmochim. Ac., 61, 611-622, 1997.

Miller, K. G., Wright, J. D., and Browning, J. V.: Visions of ice sheets in a greenhouse world, Mar. Geol., 217, 215-231, https://doi.org/10.1016/j.margeo.2005.02.007, 2005.

Montgomery, P., Hailwood, E. A., Gale, A. S., and Burnett, J. A.: The magnetostratigraphy of Coniacian-Late Campanian chalk sequences in southern England, Earth Planet. Sc. Lett., 156, 209224, https://doi.org/10.1016/S0012-821X(98)00008-9, 1998.

Mook, W. G.: Paleotemperatures and chlorinities from stable carbon and oxygen isotopes in shell carbonate, Palaeogeogr. Palaeocl., 9, 245-263, https://doi.org/10.1016/0031-0182(71)90002-2, 1971.

Mouchi, V., De Rafélis, M., Lartaud, F., Fialin, M., and Verrecchia, E.: Chemical labelling of oyster shells used for time-calibrated high-resolution $\mathrm{Mg} / \mathrm{Ca}$ ratios: a tool for estimation of past seasonal temperature variations, Palaeogeogr. Palaeocl., 373, 66-74, 2013.

NOAA Earth System Research Laboratory: NOAA Optimum Interpolation (IO) Sea Surface Temperature (SST), available at: http://www.esrl.noaa.gov/psd/data/gridded/data.noaa. oisst.v2.html, last access: 21 January 2019.

O’Brien, C. L., Robinson, S. A., Pancost, R. D., Sinninghe Damsté, J. S., Schouten, S., Lunt, D. J., Alsenz, H., Bornemann, A., Bottini, C., Brassell, S. C., Farnsworth, A., Forster, A., Huber, B. T., Inglis, G. N., Jenkyns, H. C., Linnert, C., Littler, K., Markwick, P., McAnena, A., Mutterlose, J., Naafs, B. D. A., Püttmann, W., Sluijs, A., van Helmond, N. A. G. M., Vellekoop, J., Wagner, T., and Wrobel, N. E.: Cretaceous sea-surface temperature evolution: Constraints from TEX 86 and planktonic foraminiferal oxygen isotopes, Earth-Sci. Rev., 172, 224-247, https://doi.org/10.1016/j.earscirev.2017.07.012, 2017.

Ogg, J. G., Ogg, G., and Gradstein, F. M.: A concise geologic time scale: 2016, Elsevier, 1-231, 2016.

Palmer, R. E. and Carriker, M. R.: Effects of cultural conditions on morphology of the shell of the oyster Crassostrea virginica, in: Proceedings of the National Shellfisheries Association, Vol. 69, 58-72, 1979.

Pearson, P. N., Ditchfield, P. W., Singano, J., Harcourt-Brown, K. G., Nicholas, C. J., Olsson, R. K., Shackleton, N. J., and Hall, M. A.: Warm tropical sea surface temperatures in the Late Cretaceous and Eocene epochs, Nature, 413, 481-487, 2001.

Perdiou, A., Thibault, N., Anderskouv, K., Van Buchem, F., Buijs, G. J. A., and Bjerrum, C. J.: Orbital calibration of the late Campanian carbon isotope event in the North Sea, J. Geol. Soc., 173, 504-517, 2016.

Prandle, D. and Lane, A.: The annual temperature cycle in shelf seas, Cont. Shelf Res., 15, 681-704, https://doi.org/10.1016/0278-4343(94)E0029-L, 1995.

Rausch, S., Böhm, F., Bach, W., Klügel, A., and Eisenhauer, A.: Calcium carbonate veins in ocean crust record a threefold increase of seawater $\mathrm{Mg} / \mathrm{Ca}$ in the past 30 million years, Earth Planet. Sc. Lett., 362, 215-224, 2013.

Rayner, N. A., Parker, D. E., Horton, E. B., Folland, C. K., Alexander, L. V., Rowell, D. P., Kent, E. C., and Kaplan, A.: Global analyses of sea surface temperature, sea ice, and night marine air temperature since the late nineteenth century, J. Geophys. Res.-Atmos., 108, 1-22, https://doi.org/10.1029/2002JD002670, 2003.

R Core Team: R: A language and environment for statistical computing, $\mathrm{R}$ foundation for statistical computing, Vienna, Austria, 2008.

Reid, R. E. H.: The Chalk Sea, The Irish Naturalists' Journal, 17, 357-375, 1973.

Richardson, C. A., Peharda, M., Kennedy, H., Kennedy, P., and Onofri, V.: Age, growth rate and season of recruitment of Pinna 
nobilis (L) in the Croatian Adriatic determined from $\mathrm{Mg}$ : Ca and Sr: Ca shell profiles, J. Exp. Mar. Biol. Ecol., 299, 1-16, 2004.

Roy, K., Jablonski, D., and Martien, K. K.: Invariant sizefrequency distributions along a latitudinal gradient in marine bivalves, P. Natl. Acad. Sci. USA, 97, 13150-13155, https://doi.org/10.1073/pnas.97.24.13150, 2000.

Rucker, J. B. and Valentine, J. W.: Salinity Response of Trace Element Concentration in Crassostrea virginica, Nature, 190, 10991100, https://doi.org/10.1038/1901099a0, 1961.

Sano, Y., Kobayashi, S., Shirai, K., Takahata, N., Matsumoto, K., Watanabe, T., Sowa, K., and Iwai, K.: Past daily light cycle recorded in the strontium/calcium ratios of giant clam shells, Nat. Commun., 3, 1-6, https://doi.org/10.1038/ncomms1763, 2012.

Schöne, B. R. and Gillikin, D. P.: Unraveling environmental histories from skeletal diaries - Advances in sclerochronology, Palaeogeogr. Palaeocl., 373, 1-5, https://doi.org/10.1016/j.palaeo.2012.11.026, 2013.

Schöne, B. R., Houk, S. D., Freyre Castro, A. D., Fiebig, J., Oschmann, W., KröNcke, I., Dreyer, W., and Gosselck, F.: Daily growth rates in shells of Arctica islandica: assessing sub-seasonal environmental controls on a long-lived bivalve mollusk, Palaios, 20, 78-92, 2005.

Schöne, B. R., Zhang, Z., Jacob, D., Gillikin, D. P., Tütken, T., Garbe-Schönberg, D., McConnaughey, T., and Soldati, A.: Effect of organic matrices on the determination of the trace element chemistry $(\mathrm{Mg}, \mathrm{Sr}, \mathrm{Mg} / \mathrm{Ca}, \mathrm{Sr} / \mathrm{Ca}$ ) of aragonitic bivalve shells (Arctica islandica) - Comparison of ICP-OES and LA-ICP-MS data, Geochem. J., 44, 23-37, 2010.

Schöne, B. R., Zhang, Z., Radermacher, P., Thébault, J., Jacob, D. E., Nunn, E. V., and Maurer, A.-F.: $\mathrm{Sr} / \mathrm{Ca}$ and $\mathrm{Mg} / \mathrm{Ca}$ ratios of ontogenetically old, long-lived bivalve shells (Arctica islandica) and their function as paleotemperature proxies, Palaeogeogr. Palaeocl., 302, 52-64, 2011.

Schöne, B. R., Radermacher, P., Zhang, Z., and Jacob, D. E.: Crystal fabrics and element impurities $(\mathrm{Sr} / \mathrm{Ca}, \mathrm{Mg} / \mathrm{Ca}$, and $\mathrm{Ba} / \mathrm{Ca})$ in shells of Arctica islandica - Implications for paleoclimate reconstructions, Palaeogeogr. Palaeocl., 373, 50-59, 2013.

Scotese, C.: A New Global Temperature Curve For The Phanerozoic, GSA Annual Meeting Denver, Colorado, Abstracts with Programs, Vol. 48, No. 7, 2016.

Shackleton, N. J.: Paleogene stable isotope events, Palaeogeogr. Palaeocl., 57, 91-102, 1986.

Snoeck, C., Lee-Thorp, J., Schulting, R., Jong, J., Debouge, W., and Mattielli, N.: Calcined bone provides a reliable substrate for strontium isotope ratios as shown by an enrichment experiment, Rapid Commun. Mass Sp., 29, 107-114, 2015.

Sørensen, A. M., Surlyk, F., and Jagt, J. W. M.: Adaptive morphologies and guild structure in a high-diversity bivalve fauna from an early Campanian rocky shore, Ivö Klack (Sweden), Cretaceous Res., 33, 21-41, https://doi.org/10.1016/j.cretres.2011.07.004, 2012.

Sørensen, A. M., Ullmann, C. V., Thibault, N., and Korte, C.: Geochemical signatures of the early Campanian belemnite Belemnellocamax mammillatus from the Kristianstad Basin in Scania, Sweden, Palaeogeogr. Palaeocl., 433, 191-200, 2015.

Stanley, S. M. and Hardie, L. A.: Secular oscillations in the carbonate mineralogy of reef-building and sediment-producing organisms driven by tectonically forced shifts in seawater chemistry, Palaeogeogr. Palaeocl., 144, 3-19, 1998.
Stenzel, H. B.: Aragonite and calcite as constituents of adult oyster shells, Science, 142, 232-233, 1963.

Steuber, T.: Isotopic and chemical intra-shell variations in low-Mg calcite of rudist bivalves (Mollusca-Hippuritacea): disequilibrium fractionations and late Cretaceous seasonality, Int. J. Earth Sci., 88, 551-570, 1999.

Steuber, T., Rauch, M., Masse, J.-P., Graaf, J., and Malkoč, M.: Low-latitude seasonality of Cretaceous temperatures in warm and cold episodes, Nature, 437, 1341-1344, 2005.

Strahl, J., Philipp, E., Brey, T., Broeg, K., and Abele, D.: Physiological aging in the Icelandic population of the ocean quahog Arctica islandica, Aquat. Biol., 1, 77-83, 2007.

Surge, D. and Lohmann, K. C.: Evaluating $\mathrm{Mg} / \mathrm{Ca}$ ratios as a temperature proxy in the estuarine oyster, Crassostrea virginica, J. Geophys. Res.-Biogeo., 113, 1-9, https://doi.org/10.1029/2007JG000623, 2008.

Surge, D., Lohmann, K. C., and Dettman, D. L.: Controls on isotopic chemistry of the American oyster, Crassostrea virginica: implications for growth patterns, Palaeogeogr. Palaeocl., 172, 283-296, 2001.

Surge, D. M., Lohmann, K. C., and Goodfriend, G. A.: Reconstructing estuarine conditions: oyster shells as recorders of environmental change, Southwest Florida, Estuarine, Coast. Shelf Sci., 57, 737-756, https://doi.org/10.1016/S0272-7714(02)00370-0, 2003.

Surlyk, F. and Christensen, W. K.: Epifaunal zonation on an Upper Cretaceous rocky coast, Geology, 2, 529-534, 1974.

Surlyk, F. and Sørensen, A. M.: An early Campanian rocky shore at Ivö Klack, southern Sweden, Cretaceous Res., 31, 567-576, 2010.

Tagliavento, M., John, C. M., and Stemmerik, L.: Tropical temperature in the Maastrichtian Danish Basin: Data from coccolith $\Delta^{47}$ and $\delta^{18} \mathrm{O}$, Geology, 47, 1074-1078, 2019.

Thibault, N., Husson, D., Harlou, R., Gardin, S., Galbrun, B., Huret, E., and Minoletti, F.: Astronomical calibration of upper Campanian-Maastrichtian carbon isotope events and calcareous plankton biostratigraphy in the Indian Ocean (ODP Hole 762C): Implication for the age of the CampanianMaastrichtian boundary, Palaeogeogr. Palaeocl., 337/338, 52-71, https://doi.org/10.1016/j.palaeo.2012.03.027, 2012.

Thibault, N., Harlou, R., Schovsbo, N. H., Stemmerik, L., and Surlyk, F.: Late Cretaceous (late Campanian-Maastrichtian) seasurface temperature record of the Boreal Chalk Sea, Clim. Past, 12, 429-438, https://doi.org/10.5194/cp-12-429-2016, 2016.

Uchikawa, J. and Zeebe, R. E.: The effect of carbonic anhydrase on the kinetics and equilibrium of the oxygen isotope exchange in the $\mathrm{CO}_{2}-\mathrm{H}_{2} \mathrm{O}$ system: Implications for $\delta^{18} \mathrm{O}$ vital effects in biogenic carbonates, Geochim. Cosmochim. Ac., 95, 15-34, 2012.

Ullmann, C. V. and Korte, C.: Diagenetic alteration in low-Mg calcite from macrofossils: a review, Geol. Quart., 59, 3-20, 2015.

Ullmann, C. V., Wiechert, U., and Korte, C.: Oxygen isotope fluctuations in a modern North Sea oyster (Crassostrea gigas) compared with annual variations in seawater temperature: Implications for palaeoclimate studies, Chem. Geol., 277, 160-166, 2010.

Ullmann, C. V., Böhm, F., Rickaby, R. E., Wiechert, U., and Korte, C.: The Giant Pacific Oyster (Crassostrea gigas) as a modern analog for fossil ostreoids: isotopic $(\mathrm{Ca}, \mathrm{O}, \mathrm{C})$ and elemen- 
tal (Mg/Ca, $\mathrm{Sr} / \mathrm{Ca}, \mathrm{Mn} / \mathrm{Ca})$ proxies, Geochem. Geophy. Geosy., 14, 4109-4120, 2013.

Upchurch Jr, G. R., Kiehl, J., Shields, C., Scherer, J., and Scotese, C.: Latitudinal temperature gradients and high-latitude temperatures during the latest Cretaceous: Congruence of geologic data and climate models, Geology, 43, 683-686, 2015.

van Hinsbergen, D. J., de Groot, L. V., van Schaik, S. J., Spakman, W., Bijl, P. K., Sluijs, A., Langereis, C. G., and Brinkhuis, H.: A paleolatitude calculator for paleoclimate studies, PloS one, 10, e0126946, https://doi.org/10.1371/journal.pone.0126946, 2015.

Vansteenberge, S., de Winter, N. J., Sinnesael, M., Xueqin, Z., Verheyden, S., and Claeys, P.: Benchtop $\mu \mathrm{XRF}$ as a tool for speleothem trace elemental analysis: Validation, limitations and application on an Eemian to early Weichselian (125-97 ka) stalagmite from Belgium, Palaeogeogr. Palaeocl., 538, 109460, https://doi.org/10.1016/j.palaeo.2019.109460, 2020.

Veizer, J.: Chemical diagenesis of carbonates: theory and application, Stable isotopes in sedimentary geology, 10, 3-100, 1983.

Veizer, J. and Prokoph, A.: Temperatures and oxygen isotopic composition of Phanerozoic oceans, Earth-Sci. Rev., 146, 92-104, 2015.

Voigt, S. and Schönfeld, J.: Cyclostratigraphy of the reference section for the Cretaceous white chalk of northern Germany, Lägerdorf-Kronsmoor: A late Campanian-early Maastrichtian orbital time scale, Palaeogeogr. Palaeocl., 287, 67-80, https://doi.org/10.1016/j.palaeo.2010.01.017, 2010.

Voigt, S., Friedrich, O., Norris, R. D., and Schönfeld, J.: Campanian-Maastrichtian carbon isotope stratigraphy: shelfocean correlation between the European shelf sea and the tropical Pacific Ocean, Newsl. Stratigr., 44, 57-72, 2010.

von Bertalanffy, L.: Quantitative laws in metabolism and growth, Q. Rev. Biol., 32, 217-231, 1957.

Waniek, J. J.: The role of physical forcing in initiation of spring blooms in the northeast Atlantic, J. Mar. Syst., 39, 57-82, 2003.

Warter, V., Erez, J., and Müller, W.: Environmental and physiological controls on daily trace element incorporation in Tridacna crocea from combined laboratory culturing and ultra-high resolution LA-ICP-MS analysis, Palaeogeogr. Palaeocl., 496, 32-47, https://doi.org/10.1016/j.palaeo.2017.12.038, 2018.
Watanabe, T., Suzuki, A., Kawahata, H., Kan, H., and Ogawa, S.: A 60-year isotopic record from a mid-Holocene fossil giant clam (Tridacna gigas) in the Ryukyu Islands: physiological and paleoclimatic implications, Palaeogeogr. Palaeocl., 212, 343-354, 2004.

Weiner, S. and Dove, P. M.: An overview of biomineralization processes and the problem of the vital effect, Rev. Mineral. Geochem., 54, 1-29, 2003.

Weis, D., Kieffer, B., Maerschalk, C., Barling, J., Jong, J. de, Williams, G. A., Hanano, D., Pretorius, W., Mattielli, N., Scoates, J. S., Goolaerts, A., Friedman, R. M., and Mahoney, J. B.: High-precision isotopic characterization of USGS reference materials by TIMS and MC-ICP-MS, Geochem. Geophy. Geosy., 7, Q08006, https://doi.org/10.1029/2006GC001283, 2006.

Wendler, I.: A critical evaluation of carbon isotope stratigraphy and biostratigraphic implications for Late Cretaceous global correlation, Earth-Sci. Rev., 126, 116-146, https://doi.org/10.1016/j.earscirev.2013.08.003, 2013.

Yang, D., Huang, Y., Guo, W., Huang, Q., Ren, Y., and Wang, C.: Late Santonian-early Campanian lake-level fluctuations in the Songliao Basin, NE China and their relationship to coeval eustatic changes, Cretaceous Res., 92, 138-149, https://doi.org/10.1016/j.cretres.2018.07.008, 2018.

Yoshimura, T., Tanimizu, M., Inoue, M., Suzuki, A., Iwasaki, N., and Kawahata, H.: Mg isotope fractionation in biogenic carbonates of deep-sea coral, benthic foraminifera, and hermatypic coral, Anal. Bioanal. Chem., 401, 2755, https://doi.org/10.1007/s00216-011-5264-0, 2011.

Zimmt, J. B., Lockwood, R., Andrus, C. F. T., and Herbert, G. S.: Sclerochronological basis for growth band counting: A reliable technique for life-span determination of Crassostrea virginica from the mid-Atlantic United States, Palaeogeogr. Palaeocl., 516, 54-63, 2018. 